\title{
Variation in the size and shape of Darwin's finches
}

\author{
P. R. GRANT, * I. ABBOTT, $\ddagger$ D. SCHLUTER,$\S$ \\ R. L. GURRY* AND L. K. ABBOTT+ \\ * Division of Biological Sciences, University of Michigan, \\ Ann Arbor, Michigan 48109-1048, U.S.A. \\ $\ddagger$ Institute of Forest Research, Hayman Road, \\ Como, Western Australia 6152 \\ $\S$ Department of Zoology, University of British Columbia, \\ Vancouver, Canada V6T 249
}

Six bill dimensions, and wing, tarsus and hallux lengths were measured on almost all museum specimens of Geospiza species available, and up to 20 specimens from each population of the remaining species of Darwin's finches. The data were subjected to univariate and multivariate analyses in order to provide a quantitative description of size and shape differences among populations and between species.

Each species of Geospiza varies among islands in size, and most of the remaining species do so as well. There is more variation in shape among species than among populations of the same species, especially in bill proportions. Allometric relations differ among species. Approximate morphological counterparts to the ground finch species, Geospiza, can be identified among the tree finches. There is a small amount of overlap in multivariate space between a ground finch species and a tree finch species (two cases), but no overlap between any two species within each group. Size variation among populations is not generally correlated with geographical variables such as latitude, longitude, island area or its degree of isolation. Nor do coefficients of variation show strong geographical trends. Several of the results confirm the findings of other workers from simpler and nonstatistical comparisons. In addition we have shown that the tree finches have relatively long legs (tarsi), and that these finches as well as the ground finches which spend most time scratching on the ground or climbing in cacti also have a relatively long hallux (hind toe). To interpret the various morphological patterns a knowledge is required of inter-island variation in food supply, feeding habits and the incidence of genetic exchange between populations. Recent field studies have provided some of this needed information, which helps to explain, among other things, why several populations of Darwin's finches are so unusually variable.

KEYWORDS:-Size - shape - coefficient of variation - allometry - multivariate analysis geographical trends - differentation - isolation - Galápagos.

\section{CONTENTS}

Introduction

Methods

Results

Frequency distributions Sexual dimorphism 


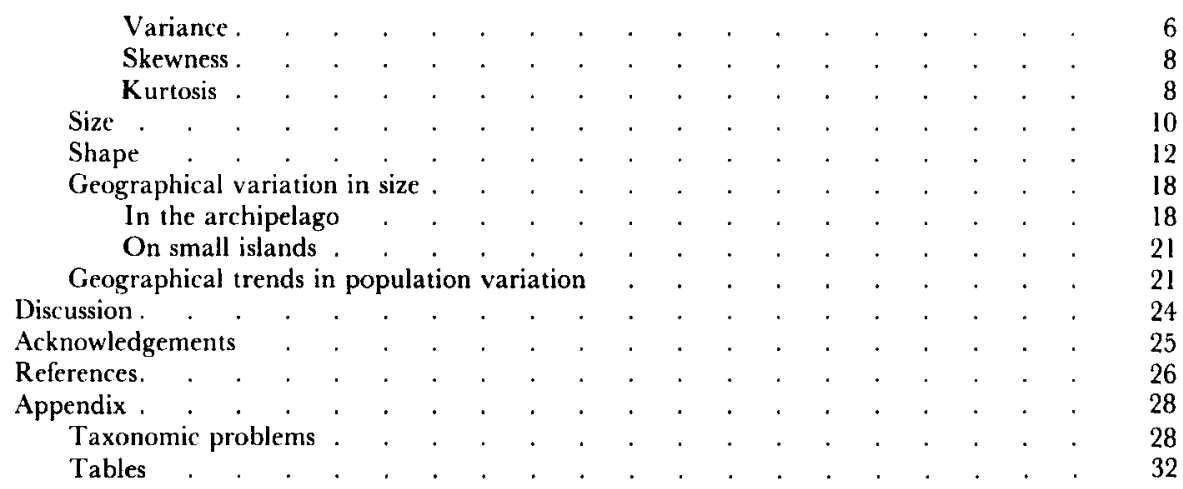

\section{INTRODUCTION}

Until recently, our understanding of the adaptive radiation of Darwin's finches was derived almost entirely from morphological studies. Swarth (1931, 1934) and Lack (1945, 1947) described the major patterns of morphological differentiation, and Bowman (1961) investigated many aspects of the functional anatomy of the finches. In contrast to the precise details of morphology, the ecological features of the finches were known only in general and qualitative terms. In the last 12 years this situation has been rectified through intensive investigations of the feeding, breeding and demography of several species on the Galápagos islands (Grant, 1984). In the course of this work questions have arisen concerning the significance of size and shape variation that cannot be answered by the results of earlier morphological studies (e.g. Grant et al., 1976; Abbott $e t$ al., 1977). Consequently we have undertaken a more comprehensive morphological study of museum specimens of Darwin's finches, and this paper presents our results.

Lack $(1945,1947)$ restricted his attention to three dimensions; wing length, bill length and bill depth. He characterized populations in terms of their means and standard deviations, ratios of means, and to a lesser extent by coefficients of variation and parametric correlation coefficients. In the present study we examined almost all specimens examined by Lack, and some others, we measured nine dimensions on each specimen, performed univariate and multivariate computations, and investigated allometric relations among populations of the same species and among species.

The results are valuable in providing a more comprehensive characterization of size and shape variation within and among Darwin's finch species than currently exists. They are also useful in answering specific ecological and evolutionary questions that require a knowledge of the relationship between morphological and ecological characteristics of individuals or species (e.g. Grant, 1981a, 1983; Grant \& Schluter, 1984; Price et al., 1984; Price \& Grant, 1984; Schluter \& Grant, 1984a, b). However, in this paper we are concerned primarily with the description of morphological variation and not with explanations for the adaptive radiation.

The species, 13 on the Galápagos islands and one on Cocos island, are listed in Table 1. 
Table 1. Darwin's finches

\begin{tabular}{lcl}
\hline Scientific name & Abbreviations used in Figs & \multicolumn{1}{c}{ English name } \\
\hline Geospiza magnirostris & MAG & Large ground finch \\
Geospiza fortis & FORT & Medium ground finch \\
Geospiza fuliginosa & FUL & Small ground finch \\
Geospiza difficilis & DIFF & Sharp beaked ground finch \\
Geospiza scandens & SCAN & Cactus finch \\
Geospiza conirostris & CON & Large cactus finch \\
Platyspiza crassirostris & CRASS & Vegetarian finch \\
Camarhynchus psittacula & PSIT & Large tree finch \\
Camarhynchus pauper & PAU & Medium tree finch \\
Camarhynchus parvulus & PARV & Small tree finch \\
Cactospiza pallida & PAL & Woodpecker finch \\
Caclospiza heliobates & HEL & Mangrove finch \\
Certhidea olivacea & OL & Warbler finch \\
Pinaroloxias inomata & IN & Cocos finch \\
\hline
\end{tabular}

Scientific names follow Bowman (1961: 20), English names follow Lack (1947: 18) but are simplified by deletion of hyphens. For further comments see Appendix.

\section{METHODS}

Specimens in juvenal plumage were ignored, and nine dimensions were measured on all of the remainder as follows: wing length, from carpal joint to the tip of the longest primary; tarsus length, from tibiotarsal joint to a distal, identifiable, undivided scute; hallux, from the base of the hind toe on the plantar surface of the foot to the base of the toe nail; upper bill length, from the anterior edge of the nostril to the tip of the upper mandible; lower bill length, from base to tip in the median plane; upper bill depth, from edge to maximum height in the vertical plane level with the anterior edge of the nares; lower bill depth, in the same plane as the previous measurement; upper bill width, at right angles to upper bill depth; lower bill width, at the base of the lower mandible at the junction with the feathers. Wing length was measured to the nearest $\mathrm{mm}$ with a ruler. All other measurements were taken to the nearest $0.1 \mathrm{~mm}$ with callipers (depths and widths) or dividers.

The study was restricted to the Geospiza species when initiated in 1973, and we measured almost all specimens available, a total of 5812. Measurements were made by I.A. except for those on 50 specimens made by P.R.G. after standardization of methods. The study was extended in 1977 to the remaining species (tree finches and warbler finch), but not more than 20 specimens of each population were measured, for a total of 780 . Measurements were made by P.R.G. and R.L.C., again after standardization. Only the measurement of hallux length was difficult to standardize. Inadvertently we measured tarsus length differently in the two groups; the distal point was taken to be one scute closer to the foot on the other finches than on the ground finches (Geospiza). Therefore we measured a few specimens of each of the tree finch and warbler finch species a second time to calculate a correction factor which was then applied in order to make comparisons with the ground finches.

Analyses were performed on the MIDAS computing system at the University of Michigan, and the details are given in the Results section. Unless stated explicitly, statistically significant differences refer to $P<0.05$. Univariate 
analyses were largely restricted to the Geospiza species (Appendix Tables), but all species were subjected to multivariate analyses.

We performed one methodological check on the reproducibility of the results. I.A. measured 17 specimens of Geospiza fuliginosa twice, about $1 \mathrm{~h}$ apart. The species was chosen because it is the smallest Geospiza species and therefore measurement error is likely to be relatively large. Correspondence between the two sets of measurements was generally good (Table 2), and needs only a few comments.

There were no significant differences in means or variances between first and second sets of measurements $(P>0.1$ in each case). Means were within $1 \%$ of each other, except for upper mandible depth $(1.4 \%)$; this is comparable to results from other studies (e.g. Grant, 1979). Repeatabilities are all very high, as high as or higher than estimates obtained from live birds on the Galápagos (Boag, 1983; Grant, 1983; Price \& Grant, 1984). Correspondences between first and second measurements are also shown by parametric correlations, and by the proportion of the 17 specimens which yielded identical first and second measurements of a trait, which we refer to as accuracy. Accuracy was highest for upper mandible length, as was repeatability, and lowest for lower mandible depth. The low repeatability of tarsus length measurements resulted from widely discrepant values in successive measurements on two specimens. In each case one measurement was in error, probably because the wrong scute was chosen for the distal point. But the errors cancelled; one was in the first sample and the other was in the second. This example shows that occasional errors of measurement or recording may have little influence on estimates of means.

\section{RESULTS}

Morphological comparison of populations will be presented in three sections. We first consider some aspects of the frequency distributions of traits: differences

Table 2. Comparison of measurements taken twice on each of 17 specimens of Geospiza fuliginosa from Islas San Cristóbal and Floreana. For each dimension $(\mathrm{mm})$ the smaller mean is expressed as a proportion of the larger mean to give a similarity value. Repeatability is an expression for differences (variance) among individuals as a proportion of total variance. Accuracy refers to the proportion of specimens with identical measurements in first and second samples

\begin{tabular}{|c|c|c|c|c|c|c|c|c|c|}
\hline & \multirow[b]{2}{*}{ Wing } & \multirow[b]{2}{*}{ Tarsus } & \multirow[b]{2}{*}{ Hallux } & \multicolumn{2}{|c|}{ Bill length } & \multicolumn{2}{|c|}{ Bill depth } & \multicolumn{2}{|c|}{ Bill width } \\
\hline & & & & Upper & Lower & Upper & Lower & Upper & Lower \\
\hline $\begin{array}{l}\text { 1st mean } \\
\text { s.E. }\end{array}$ & $\begin{array}{l}62.7 \\
0.33 \\
\end{array}$ & $\begin{array}{l}17.08 \\
0.158 \\
\end{array}$ & $\begin{array}{l}9.51 \\
0.104 \\
\end{array}$ & $\begin{array}{l}8.15 \\
0.136 \\
\end{array}$ & $\begin{array}{l}6.46 \\
0.085 \\
\end{array}$ & $\begin{array}{l}3.54 \\
0.051 \\
\end{array}$ & $\begin{array}{l}3.71 \\
0.048 \\
\end{array}$ & $\begin{array}{l}4.51 \\
0.036 \\
\end{array}$ & $\begin{array}{l}6.40 \\
0.063 \\
\end{array}$ \\
\hline $\begin{array}{l}\text { 2nd mean } \\
\text { s.E. }\end{array}$ & $\begin{array}{l}62.2 \\
0.35 \\
\end{array}$ & $\begin{array}{c}17.07 \\
0.155 \\
\end{array}$ & $\begin{array}{l}9.56 \\
0.094 \\
\end{array}$ & $\begin{array}{l}8.11 \\
0.136 \\
\end{array}$ & $\begin{array}{l}6.47 \\
0.087 \\
\end{array}$ & $\begin{array}{l}3.49 \\
0.051 \\
\end{array}$ & $\begin{array}{l}3.69 \\
0.044 \\
\end{array}$ & $\begin{array}{l}4.48 \\
0.039 \\
\end{array}$ & $\begin{array}{l}6.36 \\
0.065 \\
\end{array}$ \\
\hline $\begin{array}{l}\text { Similarity } \\
\text { of means }\end{array}$ & 0.993 & 0.999 & 0.995 & 0.995 & 0.998 & 0.986 & 0.995 & 0.993 & 0.994 \\
\hline Repeatability & 0.98 & 0.45 & 0.85 & 0.99 & 0.95 & 0.68 & 0.73 & 0.81 & 0.89 \\
\hline Accuracy & 0.59 & 0.53 & 0.35 & 0.65 & 0.35 & 0.35 & 0.29 & 0.47 & 0.47 \\
\hline
\end{tabular}




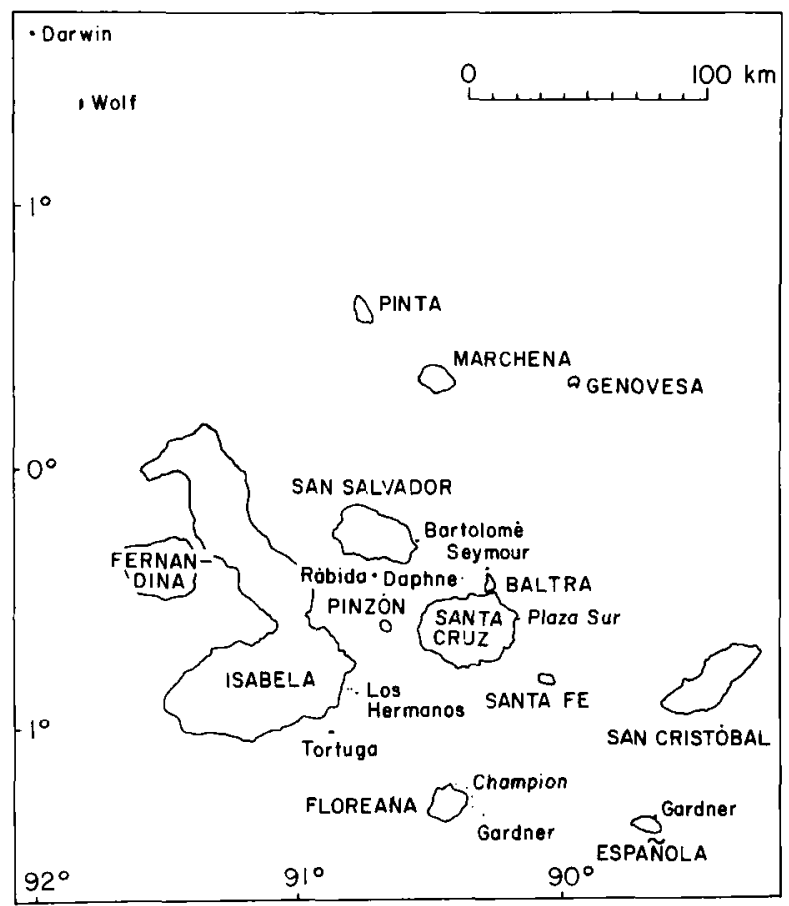

Figure 1. The Galapagos archipelago. Two islands mentioned in the Appendix are not shown: Is Enderby is between Islas Champion and Gardner near Floreana, and Is Cowley is between Islas Isabela and San Salvador but closer to Isabela. Floreana is also known as Santa María and San Salvador is also known as Santiago.

between the sexes in means; and variances, skewness and kurtosis. Next we compare size and shape variation in univariate and multivariate analyses. Finally we examine geographical trends in size and in population variation throughout the Galápagos archipelago (Fig. 1), and also specifically trends in size on small islands. Some taxonomic problems concerning nomenclature and status are discussed in the Appendix.

\section{Frequency distributions}

Sexual dimorphism

Males are consistently larger than females, by a few per cent. The degrees of dimorphism for the Geospiza species are shown in Table 3. Sample sizes for the remaining species are smaller, but these species appear to be no more dimorphic than the ground finches (see also Lack, 1945).

The sexes differ least in bill length, as has been found with the house sparrow, Passer domesticus, (Johnstón \& Selander, 1973). All species of ground finches are more dimorphic, on average, in wing length than in bill length or tarsus length, and are most dimorphic in bill width and bill depth.

Although $G$. conirostris is the most dimorphic species, as noted by Lack (1945, 1947) and Downhower (1976), it is not so by a large margin, nor is it so in all dimensions, and nor does it show the highest degrees of dimorphism: these are shown by $G$. scandens on Is San Salvador (lower bill depth) and on Is Pinta 
Table 3. Average sexual dimorphism, expressed as the mean percentage difference between males and females for all populations of Geospiza species. Populations were included only if they were represented by at least 10 male and 10 female specimens. All values in the table are positive because all male means are larger than female means

\begin{tabular}{|c|c|c|c|c|c|c|c|c|c|}
\hline \multirow[b]{2}{*}{ Species } & \multirow{2}{*}{$\begin{array}{l}\text { Number of } \\
\text { Populations }\end{array}$} & \multirow[b]{2}{*}{ Wing } & \multirow[b]{2}{*}{ Tarsus } & \multicolumn{3}{|c|}{ Upper mandible } & \multicolumn{3}{|c|}{ Lower mandible } \\
\hline & & & & Length & Depth & Width & Length & Depth & Width \\
\hline magnirostris & 6 & 3.86 & 2.23 & 2.31 & 4.65 & 3.99 & 1.16 & $4.0 \mathrm{I}$ & 3.82 \\
\hline fortis & 11 & 3.67 & 3.21 & 1.54 & 2.46 & 2.80 & 0.64 & 1.45 & 1.93 \\
\hline fuliginosa & 13 & 3.53 & 2.70 & 1.50 & 2.39 & 2.31 & 2.01 & 1.99 & 3.56 \\
\hline difficilis & 5 & 2.87 & 1.75 & 1.33 & 1.57 & 2.56 & 1.37 & 0.92 & 3.31 \\
\hline scandens & 7 & 3.95 & 3.30 & 2.07 & 2.25 & 3.72 & 1.88 & 4.44 & 5.04 \\
\hline conirosiris & 3 & 4.31 & 2.87 & 3.44 & 5.08 & 4.71 & 2.45 & 4.87 & 4.96 \\
\hline
\end{tabular}

(lower bill depth, upper and lower bill width). The population of $G$. forlis on Is Pinzón is unusual in showing reversed dimorphism: females are larger than males on average (Price, 1984).

While the degree of sexual dimorphism is typical of small passerines in not being very pronounced, it is large enough that it needs to be allowed for in comparisons of populations or species when the sexes are unequally represented. Price (1984) has examined the variation in sexual dimorphism among populations in detail.

\section{Variance}

There is significant heterogeneity in variances among some samples. Data from just one species are used to illustrate heterogeneity in levels of variation among populations of the same species (Table 4). Coefficients of variation are used to reduce, if not to eliminate altogether, the effects of scale (see Van Valen, 1978; Rohlf et al., 1983), because population means differ. Only males are used because they are larger on average than females and so should not be combined with them, and their samples are generally greater. Several populations of G. difficilis differ from each other in their degrees of variation in two bill dimensions (Table 4). These differences in coefficients of variation do not vary systematically with differences in means.

Table 4. $F$ values for comparisons of male samples of $G$. difficilis, calculated from squared coefficients of variation. Two-tailed probability values are indicated by italics $(<0.05)$ and boldface $(<0.01)$

\begin{tabular}{lcccccc}
\hline & \multicolumn{7}{c}{ Upper mandible length } \\
\cline { 2 - 7 } Lower bill width & Santa Cruz & San Salvador & Genovesa & Pinta & Wolf & Darwin \\
\hline Santa Cruz & - & 1.59 & $\mathbf{2 . 4 6}$ & 2.92 & 1.59 & 1.15 \\
San Salvador & 1.77 & - & 1.55 & 1.84 & 1.00 & 1.38 \\
Genovesa & 1.66 & 1.07 & - & 1.19 & 1.54 & $\mathbf{2 . 1 4}$ \\
Pinta & $\mathbf{5 . 1 4}$ & $\mathbf{2 . 9 0}$ & $\mathbf{3 . 0 9}$ & - & 1.84 & 2.54 \\
Wolf & 1.54 & 1.15 & 1.07 & $\mathbf{3 . 3 3}$ & - & 1.38 \\
Darwin & 1.07 & $\mathbf{1 . 6 6}$ & 1.55 & $\mathbf{4 . 8 1}$ & 1.41 &.- \\
\hline
\end{tabular}


Table 5. Average coefficients of variation for male samples $(\mathcal{N} \geqslant 10)$ of Geospiza species, with minimum and maximum coefficients for each species shown below in italics. Coefficients for Fringilla species on Atlantic islands (Grant, 1979) and for Carpodacus maxicanus on Californian islands (Power, 1983) are provided for comparison. Sample sizes of original measurements are comparable in all three studies. The total bill depth was measured on Carpodacus specimens

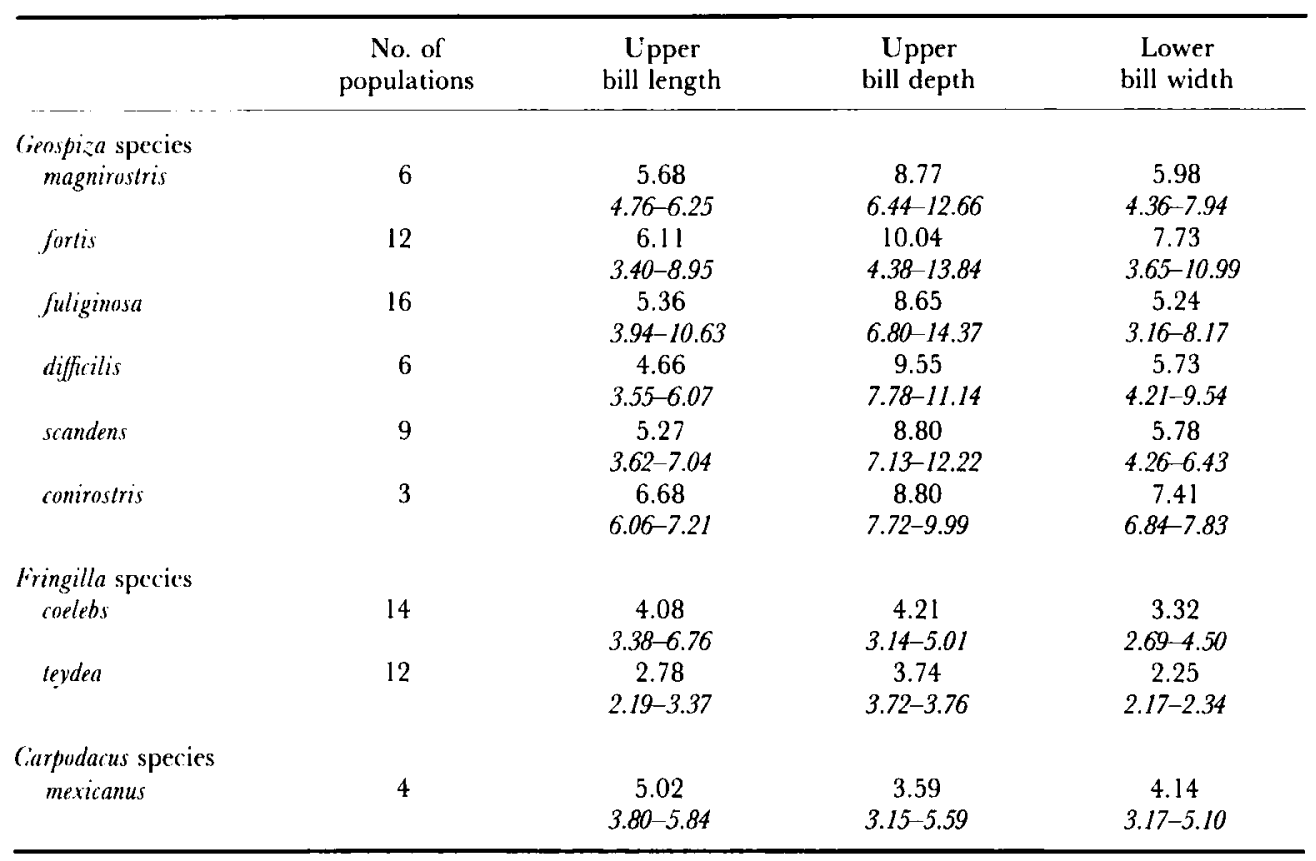

Species also differ from each other in their levels of variation. The bill data for Geospiza species are summarized in Table 5. For example, the average coefficient of variation for upper bill length is significantly greater in $G$. conirostris than in $G$. difficilis $\left(t_{7}=3.22 ; P<0.002\right)$. In general, species with largest means have the largest coefficients of variation (see also Grant et al., 1976; Abbott et al., 1977). The average coefficients of variation confirm Lack's (1947) finding that $G$. fortis is the most variable species, on average. However, it is not the largest species.

The coefficients for bill length and depth are higher than those reported by Bowman (1961) from Lack's data, because Lack's samples were restricted to male specimens in fully black plumage, whereas ours include all males. Even so, when we excluded specimens in brown plumage and reanalysed just bill depth data we found almost as many increases (23) in the resulting coefficients of variation as decreases (25). Lack measured total bill depth which, being larger, should be subject to smaller measurement error than measurements of each mandible separately. Note that coefficients are generally much larger in the ground finches than in island populations of other finch species (Table 5) that have been studied in similar detail.

Dimensions covary positively. A population with a large average wing length, for example, tends to have large average tarsus and bill dimensions as well. Similarly, coefficients of variation in a population tend to be relatively large, or 
relatively small, for all dimensions. Covariation is demonstrated by the numerous positive correlations among traits within populations, and by large Kendall coefficients of concordance, $W$ (Sokal \& Rohlf, 1981), calculated separately for means and for coefficients of variation. As tested by $\chi^{2}$, in each of the six Geospiza species there is significant concordance among populations in the relative size of traits; this applies to males and females, treated separately. The same result is obtained for coefficients of variation. Here only males were tested. The one exception is $G$. conirostris $\left(W=0.26 ; \chi_{2}^{2}=4.67 ; 0.05<P<0.1\right.$ ). But this species is not exceptional when the analysis is restricted to the six beak variates $\left(W=0.78 ; \chi_{2}^{2}=9.33 ; P<0.01\right)$.

\section{Skewness}

Samples of 25 individuals or more of either sex were tested for skewness following the procedure of Snedecor \& Cochran (1967). Five-hundred-and-sixty tests were performed: eight traits (hallux excluded) in 70 samples. Five per cent of these (28) would be expected to yield a significant departure from normality at $P<0.05$. In fact 113 were significant at this level. Male and female distributions were skewed with approximately equal frequency, in both directions.

The high number of skewed distributions is partly explained by the prevalence of positive correlations and concordance among all traits in all species. As a result, a skewed distribution in one trait is likely to be accompanied by a skewed distribution in the same direction in other traits. A test that circumvents this problem of dependence is a comparison of the incidence of significant skewness in each dimension with the random expectation of $5 \%$ of 70 (samples), i.e. 3.5. Measured against this expectation, distributions are much more often skewed than expected by chance (Table 6).

There is significant heterogeneity among the species in the frequency of positive and negative skewness $\left(\chi_{5}^{2}=23.56 ; P<0.001\right)$. Individually, two species show significant heterogeneity among skewed samples. G. fortis samples $(\mathcal{N}=12)$ that have skewed distributions are predominantly positively skewed (Binomial test, 2-tailed; $P=0.06$ ) whereas the trend is opposite for $G$. fuliginosa samples $(\mathcal{N}=15 ; P=0.006)$.

\section{Kurtosis}

Samples of 11 individuals or more of either sex were tested for kurtosis (see Snedecor \& Cochran, 1967). The main results (Table 6) are, first kurtosis is much more frequent than expected by chance (at the $5 \%$ level), second it is more frequent than skewness, and third flat-topped distributions (platykurtosis) predominate. Unlike skewness, there is no heterogeneity among species in the directions of kurtosis.

Three systematic forces could contribute to these trends in variance, skewness and kurtosis; they are natural selection, growth and hybridization. Since the samples are composites of subsamples taken in different years they could be annually heterogeneous. Different selection episodes in different years could be responsible for annual differences in mean size (cf. Boag \& Grant, 1981). Alternatively size-related age compositions might vary from year to year and distort the frequency distributions in different directions. The same effect could be produced by varying frequencies of hybridization, although the directions of 
Table 6. The number of samples of Geospiza species with significant $(P<0.05)$ skewness or kurtosis. Positive kurtosis is leptokurtosis and negative kurotosis is platykurtosis; note the predominance of negative kurtosis

\begin{tabular}{|c|c|c|c|c|c|c|c|c|c|c|c|}
\hline & Wing & Tarsus & \multicolumn{2}{|c|}{ Bill length } & \multicolumn{2}{|c|}{ Bill depth } & \multicolumn{2}{|c|}{ Bill width } & & \multicolumn{2}{|c|}{ Summary } \\
\hline Positive & 3 & 3 & 6 & 9 & 4 & 10 & 9 & 10 & Only positive & 12 & 12 \\
\hline Negative & 5 & 7 & 10 & 5 & 16 & 3 & 5 & 5 & Both & 8 & 19 \\
\hline Total & 8 & 10 & 16 & 14 & 20 & 13 & 14 & 15 & Neither & 26 & 20 \\
\hline Negative & 13 & 17 & 21 & 15 & 11 & 14 & 18 & 22 & & & \\
\hline Total & 17 & 20 & 26 & 20 & 17 & 17 & 21 & 24 & & & \\
\hline
\end{tabular}


skewness in the (small) G. fuliginosa and the (medium) G. fortis are the opposite of those expected from an hypothesis of hybridization between them. Either singly or together these factors could give rise to composite distributions that depart from normality in any of the observed ways. However, these distortions are not likely to have major effects on the estimates of variances (or means), as indicated by the good agreement between estimates derived from measurements of live birds over periods of a few weeks or months and estimates based on measurements of composite samples of museum specimens; compare coefficients of variation in Abbott et al. (1977), Grant \& Grant (1979, 1983) and Boag \& Grant $(1984 a$, b) with values in Table 5 or those published in Lack (1945) or Bowman (1961).

\section{Size}

There are two ways to measure size, by weighing birds and by measuring dimensions. Some weights have become available in recent years in the course of ecological field studies, and they are summarized in Table 7. Each Geospiza species varies in mean weight significantly $(P \ll 0.05)$ among islands (ANOVAS). The most variable species is $G$. difficilis: average weights of males range from $11.6 \mathrm{~g}$ on Genovesa to $26.8 \mathrm{~g}$ on San Salvador. Marked and consistent differences between species are also evident in Table 7 .

Table 7. The mean weights of males in partially or wholly black plumage in the dry season. Sample sizes are in parentheses. Data are from several field studies: Smith et al. (1978), Grant \& Grant (1980), Schluter (1982), Schluter \& Grant (1984b), Boag \& Grant (1984b) and unpublished. B. Borrero is on the north side of Is Santa Cruz, and B. Academía is on the south side

\begin{tabular}{|c|c|c|c|c|c|c|}
\hline \multirow[b]{2}{*}{ Island } & \multicolumn{6}{|c|}{ Geospiza species } \\
\hline & magnirostris & forlis & fuliginosa & difficilis & scandens & conirostris \\
\hline Pinta & $36.9(18)$ & $17.7(11)$ & $11.3(72)$ & $19.0(23)$ & $23.0(12)$ & \\
\hline Marchena & $32.6(12)$ & $17.4(4)$ & $9.7(11)$ & & $23.8(2)$ & \\
\hline Genovesa & $35.5(27)$ & & & $11.6(56)$ & & $25.3(26)$ \\
\hline Wolf & & & & $20.5(22)$ & & \\
\hline Darwin & & & & $25.5(4)$ & & \\
\hline San Salvador & $39.0(5)$ & $20.7(8)$ & $14.7(30)$ & $26.8(13)$ & & \\
\hline Fernandina & $28.9(3)$ & $19.6(5)$ & $12.7(15)$ & $19.6(11)$ & & \\
\hline Tortuga & & & $16.0(12)$ & & & \\
\hline Española & & & $14.6(16)$ & & & $31.6(19)$ \\
\hline Daphne & & $16.5(82)$ & & & $21.6(30)$ & \\
\hline B. Borrero & & $19.6(20)$ & $13.2(24)$ & & $20.4(5)$ & \\
\hline B. Academía & & $23.0(62)$ & $14.1(9)$ & & $22.6(6)$ & \\
\hline Santa Fe & & & $13.1(5)$ & & 20.3 & \\
\hline Hermanos & & & $16.5(2)$ & & & \\
\hline Champion & & $21.4(4)$ & & & $21.4(6)$ & \\
\hline Isabela & & $19.4(18)$ & $14.5(17)$ & & & \\
\hline Rábida & $34.0(4)$ & & $14.2(21)$ & & $21.5(8)$ & \\
\hline Gardner & & & $14.6(16)$ & & & $27.6(10)$ \\
\hline
\end{tabular}

Additional mean weights of tree finches, sexes combined: Platyspiza crassirostris 34.7 (2; Santa Cruz); 29.3 (12; Pinta); 33.9 (4; San Salvador): Cactospiza pallida 20.2 (3; Santa Cruz): Camarhynchus psittacula 17.2 (2; Santa Cruz); 19.4 (7; Pinta): Camarhynchus parvulus 12.8 (81; Santa Cruz): Certhidea olivacea 9.3 (14; Santa Cruz); 8.8 (13; Pinta); 8.3 (8; Genovesa); 7.9 (7; Española); 8.9 (9; Gardner by Española); 8.8 (3; Hermanos). 
Table 8. Parametric correlation coefficients between mean weight and mean dimensions of male samples of Geospiza species. Mean weights are listed in Table 7

\begin{tabular}{lcccc}
\hline & & \multicolumn{3}{c}{ Dimensions } \\
\cline { 3 - 5 } Go. of & $\begin{array}{c}\text { Nospiza species } \\
\text { populations }\end{array}$ & Wing length & Tarsus length & Bill length \\
\hline magnirostris & 5 & 0.19 & 0.23 & 0.59 \\
fortis & 8 & $0.79^{*}$ & $0.79^{*}$ & $0.73^{*}$ \\
fuliginosa & 11 & $0.90^{* *}$ & $0.87^{* *}$ & $0.80^{* *}$ \\
difficilis & 6 & $0.81^{*}$ & $0.92^{* *}$ & 0.66 \\
scandens & 7 & 0.35 & 0.41 & 0.52 \\
\hline
\end{tabular}

Statistically significant corrclations are indicated by $* P<0.05 ; * * P<0.01$.

All measured traits covary positively in the largest samples of museum specimens. Which trait has the strongest relationship to weight? An analysis of population means shows that wing and tarsus are generally correlated more strongly with weight than are bill dimensions, but by not much. Table 8 gives the results of separate analyses for each Geospiza species. The same result is obtained when all Geospiza species are considered simultaneously (Fig. 2). Correlation coefficients are high for the relationship between weight and wing $(r=0.96$; d.f. $=38 ; P<0.001)$ and between weight and tarsus $(r=0.96 ;$ d.f. $=38$; $P<0.001)$; wing and tarsus are also strongly correlated with each other $(r=0.97$; d.f. $=38 ; P<0.001$; see also Fig. 3$)$. The slopes of the functional regressions (see Harvey \& Mace, 1982) of wing or tarsus on weight with lntransformed data are also similar to each other: 0.286 for wing and 0.252 for
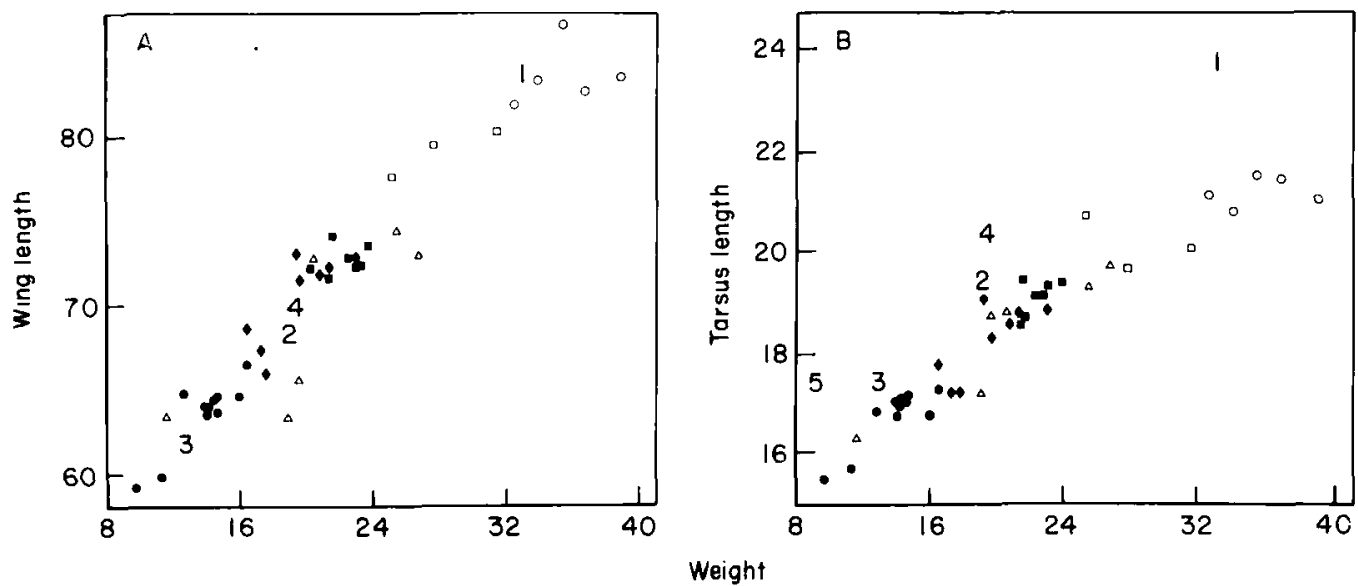

Figure 2. A, mean wing length $(\mathrm{mm})$, and $B$, tarsus length $(\mathrm{mm})$, as functions of mean weight $(\mathrm{g})$ for adult male samples of $G$. magnirostris $(O), G$. conirostris $(\square), G$. difficilis $(\triangle), G$. scandens $(\square), G$. fortis $(\bullet)$ and (i. fuliginosa (- Numbers refer to the average values of tree finch species, male and females combined; 1, Plalyspoza crassirostris;; Camarhynchus psittacula; 3, C. parvulus; 4, Cactospiza pallida; 5, Cerlhidea olivacea. Note the similarity of ground finches and tree finches in $\mathbf{A}$, but the proportionately longer tarsi of tree finches in B. Certhidea olivacea, not shown in A, has a mean wing length of $53.2 \mathrm{~mm}$. 

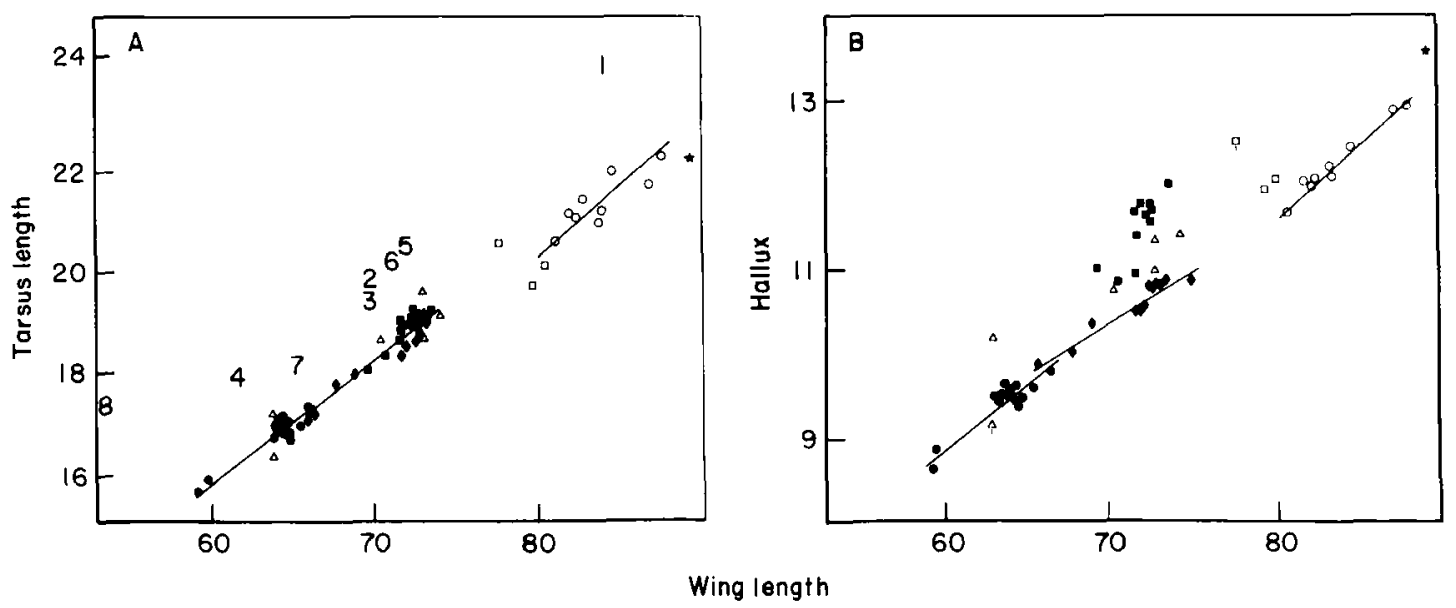

Figure 3. A, mean tarsus length $(\mathrm{mm})$, and $\mathbf{B}$, hallux $(\mathrm{mm})$, in relation to wing length for malc samples. Symbols: $\bigcirc, G$. magnirostris; $\square, G$. conirosiris; $\triangle, G$. diffilis; $\square, G$. scandens; $\bullet, G$. fortis;,$G$, fuliginosa. Functional regression lines are drawn through the population means of $G$. magnirostris $(O)$, G. fortis (-) and $G$. fuliginosa (O). Numbers: 1, Platyspiza crassirostris; 2, Camarhynchus psittacula; 3, C. pauper; 4, C. parvulus; 5, Cactospiza pallida; 6, C. heliobates; 7, Pinaroloxias inornala; 8, Certhidea olivacea. Tree finches are not included on $B$ because hallux length may not have been measured in the same way on these and ground finches (see text). The exinct populations of $G$. magnirostris on Islas Floreana and San Cristóbal (combined) are identified by a star. Vertical lines beneath symbols identify populations of $G$. conirostris and $G$. difficilis on Is Genovesa (see text for further details).

tarsus. Therefore either wing or tarsus serves as a good indicator of size in comparisons of populations of the same or different species.

Variation in size among several correlated dimensions can also be characterized by the first component in a Principal Components Analysis (e.g. see Gould \& Johnston, 1972). The analysis is useful for characterizing shape variation simultaneously, and we employ and discuss it below.

\section{Shape}

Although size variation predominates among populations there are shape differences among species. Shape changes in relation to size in a different manner among the species. Simple bivariate plots illustrate the main differences (Figs 3 \& 4).

A striking difference in proportions among species is shown in Fig. 3. Although hallux increases in length as body size increases among populations, for a given body size hallux is distinctly longer in $G$. difficilis, $G$. scandens and $G$. conirostris than in the other three species of ground finches. $G$. scandens, the species which spends most time perched or climbing on cactus, has proportionately the longest hallux. The population of $G$. conirostris on Is Genovesa is a similar cactus specialist (Grant \& Grant, 1981, 1982), and it has the longest relative hallux for its species. G. difficilis forages mainly on the ground, scratching in the litter with its feet (Schulter, 1982). The population of $G$. difficilis that does this to the least amount is on Is Genovesa, and it has the shortest hallux both absolutely and relatively (Fig. 3). Thus the hallux is well 

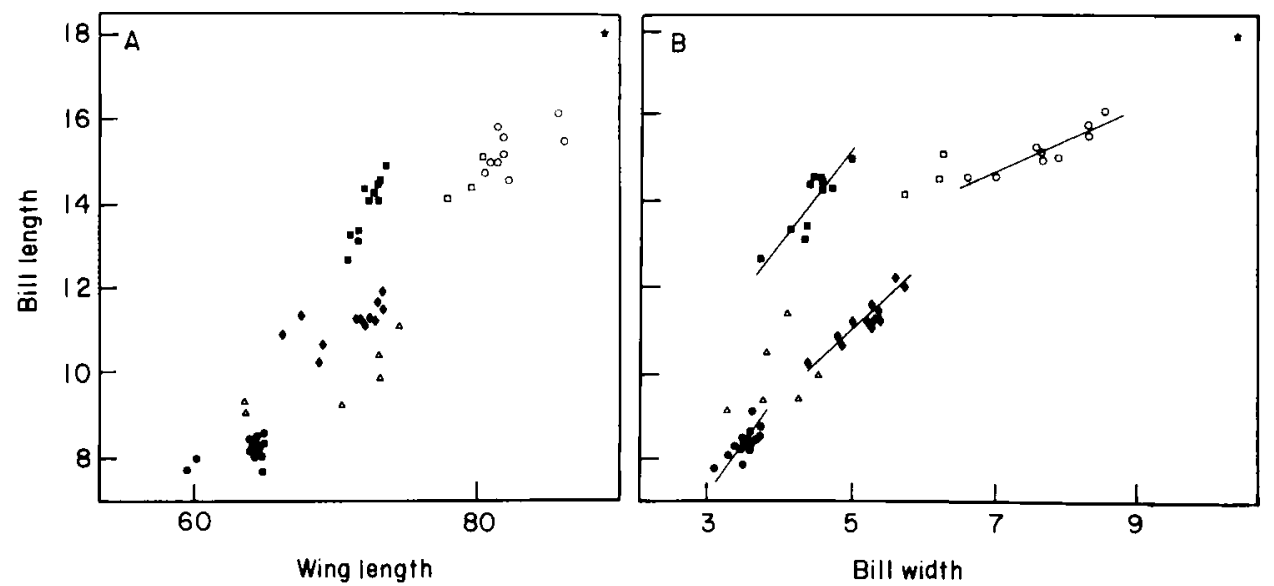

Figure 4. A, mean bill length $(\mathrm{mm})$ in relation to mean wing length $(\mathrm{mm})$; B, mean bill length in relation to mean bill wid th $(\mathrm{mm})$ for male samples. Symbols: $O, G$. magnirostris; $\square, G$. conirostris; $\triangle, G$. difficilis;

$\square, G$. scandens;, G. forlis;, G. fuliginosa. Functional regression lines have been drawn through the population means of four species in B. In B (only) the G. magnirostris point closest to the $G$. conirostris cluster represents the Is Darwin sample (see also the Appendix and Fig. 8). The extinct populations of $G$. magnirostris on Isla Floreana and San Cristóbal (combined) are identified by a star.

developed in those ground finches that climb or scratch on the ground most frequently.

All tree finches have long tarsi relative to body weight, but not long (or short) wings relative to body weight (Fig. 2). Therefore wing length is an appropriate size measure to use as a standard for comparison of other body parts. The hallux is relatively long in the two species of tree finch that most frequently cling to trunks and large branches, Camarhynchus psittacula and Cactospiza pallida. It is relatively short in all of the rest, but comparisons with ground finches may not be reliable because of possible measurement differences (p. 3). Nevertheless it is clear that tree finches and ground finches differ in hind limb length in relation to body size.

Within the ground finches the most notable shape variation is in the bill. Bill length does not scale in a simple manner to body size within the genus (Fig. 4A): mean bill lengths of the six species do not lie on a single straight line, and bill length increases with body size faster in some species, such as $G$. scandens, than in others, such as $G$. fortis. Also, species differ from each other most in bill shape (Fig. 4B): again all points for the six species do not lie on a single line of allometry, and bill shape changes differently among populations of the different species. Bill shape variation is also pronounced among the tree finches (see below).

Since much of the variation in proportions accompanies variation in size, it is desirable to assess the amount of shape variation that remains after the effects of size variation have been removed. This can be accomplished by Principal Components Analysis; if the first component adequately characterizes size variation, subsequent components represent residual shape variation (Flessa \& Bray, 1977). Such variation is therefore largely, if not entirely (Mosimann \& James, 1979; Humphries el al., 1981), independent of size.

We first use PCA to describe trends of variation among individuals within 
populations of species. The 14 species were subjected separately to PCA in the following way. First hallux was excluded because of a relatively low repeatability between measures. We simplified the data further by excluding lower bill length and upper bill width, and by combining upper and lower bill depth; thus one length, depth and width measure of the bill was used. All data were In-transformed before computation. Sexes were pooled within populations. To minimize the effects of outliers on estimates of variance-covariance we then deleted the individuals with the minimum and maximum values for each trait. Finally, for each species, populations were pooled across islands to increase sample sizes. Principal components were calculated from the variancecovariance matrix.

The first two components together account for $63.6 \%$ (Geospiza difficilis) to $86.4 \%$ (Camarhynchus pauper) of the variance among individuals. The magnitude of factor loadings (Fig. 5) on the first two principal components show the relative contribution to the major synthetic axes made by the particular dimensions.

The main results are, (1) almost all factor loadings on PC1 are positive, and (2) factor loadings of wing and tarsus on PC2 are almost all positive but those for bill dimensions are always of mixed sign. The first result supports our interpretation of $\mathrm{PCl}$ as an overall size axis, as does the similarity of factor

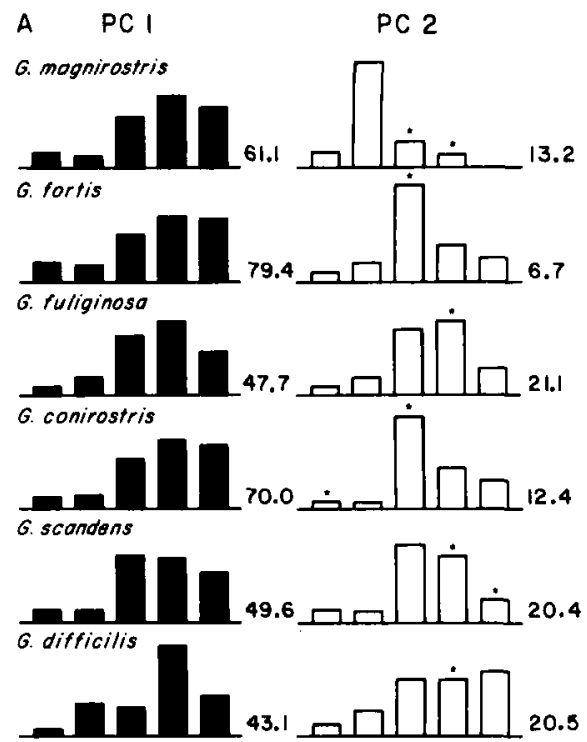

WL TL BL BD BW

WL TL BL BD BW

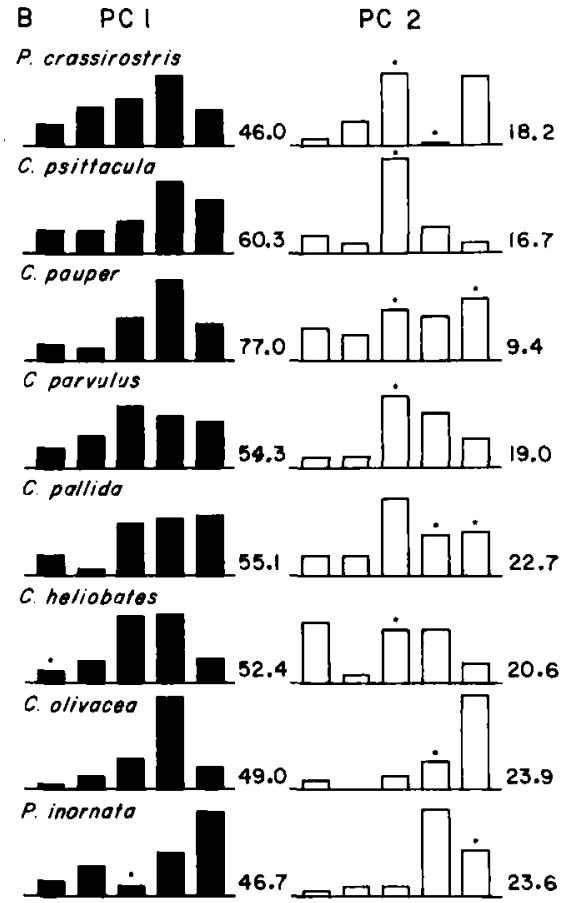

WL TLBL BD BW WL TLBL BD BW

Figure 5. Factor loadings on the first two principal components based on individuals within populations. The scale from 0 to 100 is shown at the bottom of the figure, and the percentage variance explained by each component is shown at the right of each histogram. Negative loadings are indicated by an asterisk. Symbols: WL, wing length; TL, tarsus length; BL, bill length; BD, bill depth; BW, bill width. 
loadings on PCl among the species (cf. Mosimann \& James, 1979; 455). We interpret PC2 as a shape axis dominated by bill proportions. The importance of bill proportions is consistent with the patterns revealed by the bivariate analyses (Figs 3 \& 4).

These interpretations apply to both the ground finch group and the tree finch group. In both groups bill depth is usually the greatest contributor to PC1, and bill length is the commonest major contributor to PG2. Relative factor loadings for the five dimensions are very uniform among species in the two groups. There are low values for the least variable ones, wing and tarsus, and high ones for the three bill dimensions.

Species differ among each other most in bill shape relations, as indicated by the greater heterogeneity in factor loadings on PC2, even though some individual pairs of species such as $G$. fortis and $G$. conirostris are very similar. There are no consistent shape differences between the ground finch group of species and the tree finch group. The most different pair of species are Certhidea olivacea and Pinaroloxias inornata, which are the two species with the proportionately longest beaks: bill depth and bill width dominate both axes, although in opposite ways. However, variation in $P$. inornata is estimated from only 20 specimens, which is inadequate because samples of about 50 or more are normally required for stability of covariances (Kunkel $e l$ al., 1980). This species and the other two represented by small samples (Camarhynchus pauper and Cactospiza heliobates) are included in Fig. 5 for completeness.

To compare species on the same axes, we next performed a principal components analysis with separate populations of each species, i.e. not pooled. For this analysis the averages of the unscaled male and female means for each trait except hallux in each population were used, and In-transformed prior to computation. The major trends of variation among populations and species are shown in Fig. 6. The first two components, constituted in a similar way to those in the previous analyses, account for $96.5 \%$ of the total variance. The factor loadings are similar to those from the previous analyses, except that upper mandible length and lower mandible length more clearly make the greatest contribution to PC2 (Table 9). PCl is again a size axis; mean PC1 scores of 11 of the species are positively correlated with their average weights calculated from the data in Table $7(r=0.91$; d.f. $=9 ; P<0.01)$.

Figure 6 shows that all species are well separated in two-dimensional space, with overlap occurring between one ground finch and one tree finch species in two cases, but never between species in the same group. Separation between the two groups occurs more along the beak shape axis (PC2) than along the size axis (PCl); for a given body size (PCl), tree finches and ground finches have different bill proportions. But the two groups do not cluster in different parts of the two-dimensional plot: there is broad overlap among them.

Separate treatment of the two groups of finches (Fig. 7) provides a way of illuminating another feature of Fig. 6: that is, most ground finch species have counterparts in the tree finch group as represented in these two-dimensional characterizations. Thus there is a good correspondence between $G$. magnirostris and Platyspiza crassirostris; between $G$. scandens and Cactospiza pallida; between G. fuliginosa and Camarhynchus parvulus; and between $G$. fortis and G. conirostris combined and Camarhynchus psittacula. Only G. difficilis does not have a tree finch counterpart. The two species with thin pointed bills missing from Fig. 7B, 


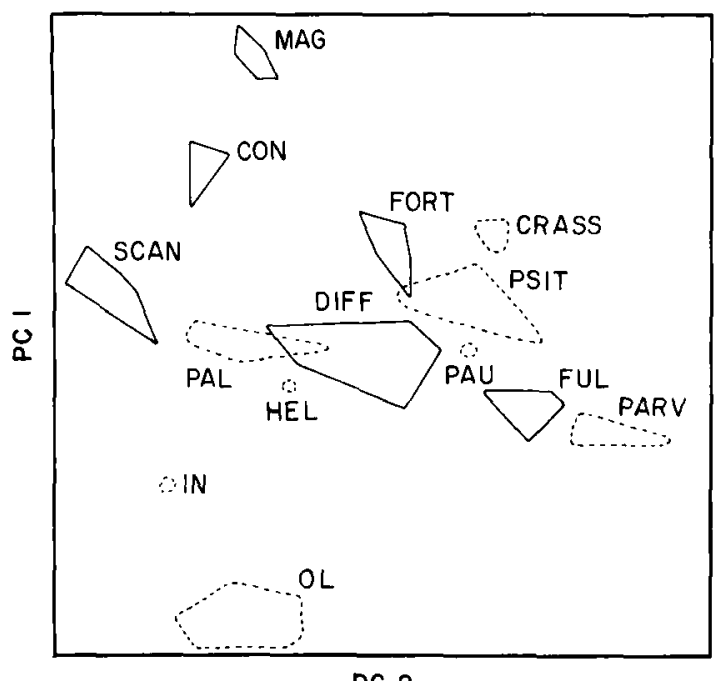

Figure 6. Principal components plot of all 14 species, based on population means. PCl accounts for $90.4 \%$ of the variance among populations and species, and represents body size increasing away from the origin. $\mathrm{PC} 2$ accounts for an additional $6.1 \%$ of the variance, and represents bill shape that becomes relatively short and deep in progression away from the origin. Minimum area polyhedra are drawn around the population points for each species. See Table 1 for explanation of abbreviations.

Certhidea olivacea and Pinaroloxias inornala, are not the counterparts of $G$. difficilis (see Fig. 7C). The synthetic axes of Figs 6 \& 7 being compared do not differ very much, nor do the factor loadings (Table 9).

Figure 7 also shows that within each group of finches (tree, ground) the orientation of intraspecific, cross-population, axes of variation are similar. But in neither group is major interspecific variation a simple extension of major intraspecific (interpopulation) variation. The closest to such a simple extrapolation is shown by the sequence of three Geospiza species of increasing size; fuliginosa, fortis and magnirostris (see also Grant, 1981b; Price et al., 1984).

Table 9. Factor loadings on the first two principal components obtained for the analyses depicted in Figs $6 \mathrm{~A}$ and $7 \mathrm{~B}-\mathrm{D}$

\begin{tabular}{|c|c|c|c|c|c|c|c|c|}
\hline & \multicolumn{4}{|c|}{$\mathrm{PCl}$} & \multicolumn{4}{|c|}{$\mathrm{PC} 2$} \\
\hline & A & B & C & D & $\mathrm{A}$ & B & $\mathrm{C}$ & D \\
\hline Wing length & 0.152 & 0.149 & 0.247 & 0.188 & 0.009 & -0.080 & 0.005 & 0.166 \\
\hline Tarsus length & 0.049 & 0.119 & 0.255 & 0.122 & -0.017 & -0.100 & 0.045 & 0.141 \\
\hline Upper bill length & 0.229 & 0.340 & 0.281 & 0.137 & -0.632 & -0.596 & -0.617 & 0.668 \\
\hline Lower bill length & 0.179 & 0.317 & 0.192 & 0.053 & -0.707 & -0.605 & -0.692 & 0.689 \\
\hline Upper bill depth & 0.464 & 0.441 & 0.368 & 0.498 & 0.138 & 0.165 & 0.053 & -0.120 \\
\hline Lower bill depth & 0.620 & 0.494 & 0.546 & 0.624 & 0.278 & 0.399 & 0.321 & -0.174 \\
\hline Upper bill width & 0.353 & 0.352 & 0.377 & 0.366 & 0.044 & 0.111 & 0.076 & 0.012 \\
\hline Lower bill width & 0.408 & 0.434 & 0.428 & 0.395 & 0.053 & 0.251 & 0.163 & 0.009 \\
\hline $\begin{array}{l}\text { Percentage variance } \\
\text { (cumulative) }\end{array}$ & 90.4 & 90.8 & 79.6 & 94.9 & 96.5 & 98.9 & 95.5 & 98.4 \\
\hline
\end{tabular}

A, all finches; B, ground finches; C, tree finches, excluding Certhidea and Pinaroloxias; D, all tree finches. 


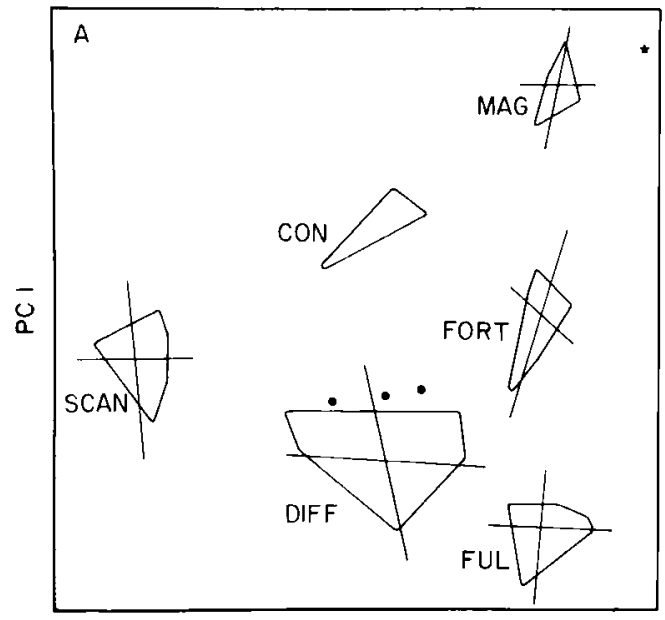

PC 2

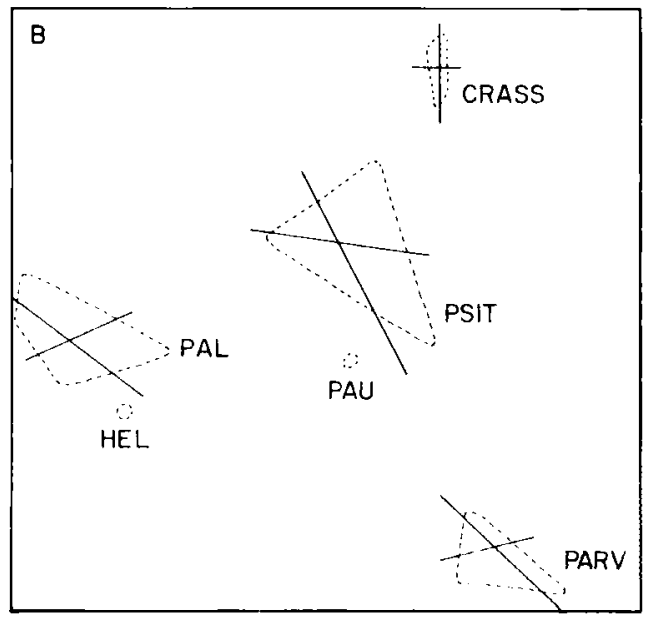

PC 2

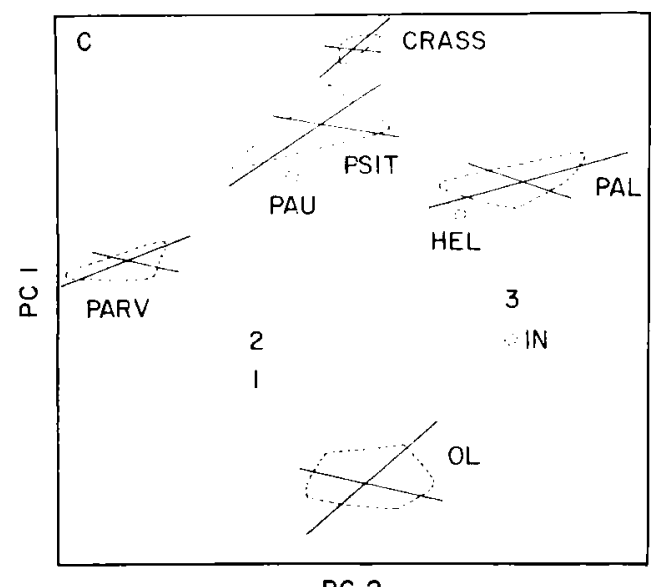

PC 2

Figure 7. Principal components plot for A, ground finches, B, tree finches except for Certhidea olivacea and Pinaroloxias inornata and $\mathrm{C}$, all tree finches. Lines are projections of the separate interpopulation (intraspecific) principal components 1 and 2 onto the principal components axes for all species combined; the longer lines represent $\mathrm{PCl}$, being approximately vertical in A, sloping upwards to the left in $B$ and upwards to the right in $\mathrm{C}$. Cumulative percentage variance explained by the two interpopulation components ranges from $87 \%$ (Certhidea olivacea) to almost $100 \%$ (Camarhynchus psittacula). Factor loadings on the components in the three plots are listed in Table 9. The solid circles identify three specimens of $G$. difficilis from Is Floreana, which were not used in the analysis: the left two are female specimens in the British Museum and the right is a male in the Royal Stockholm Museum (sce also the Appendix). The star identifies the sample of four male specimens of the extinct form of $G$. magnirostris on Islas Floreana and San Cristóbal. Points 1 and 2 identify specimens that have been labelled as 'conjunctus' and 'aureus' respectively and considered hybrids of Camarhynchus parvulus and Certhidea olivacea; point 3 identifies a specimen referred to as 'giffordi' and thought to be a hybrid of Cactospiza pallida and Certhidea olivacea (Lack, 1945; Bowman, 1961). Their intermediate positions on the first two Principal Component axes are consistent with these interpretations. See Table 1 for explanation of abbreviations. 
The areas enclosed in the polyhedra in these Figures give an approximate measure of the degree to which populations of a species have become morphologically differentiated on different islands. Among the ground finches G. difficilis (six populations) is more differentiated than all others. Among the tree finches Certhidea olivacea (14 populations) is perhaps the most differentiated species, followed closely by Camarhynchus psittacula (five populations) which is clearly more differentiated than its congener $C$. parvulus, represented by the same number of populations (five). Platyspiza crassirostris has scarcely differentiated at all.

\section{Geographical variation in size}

\section{In the archipelago}

Geographical variation in size takes three forms in the archipelago: along altitudinal gradients, between localities at the same altitude on the same island, and between islands. Variation along altitudinal gradients cannot be examined with museum specimens because so few have altitude data recorded on the labels. It is strongly suspected to occur, but not demonstrated, from our measurements of live individuals of $G$. fortis on the south side of Is Santa Cruz, on Is Pinta and on Volcan Alcedo on Is Isabela (S. J. Millington, pers. comm.; D. S. pers. obs.). Character means were larger at higher elevations than lower ones in each case.

Lack (1945, 1947) commented on the smaller size of G. fortis from the northern part of Is Isabela than from the southern part of the island, and treated the samples of this species (and others) separately. We have confirmed through ANOVAS that there is small but statistically significant $(P \ll 0.05)$ geographical variation in wing, tarsus and bill traits of $G$. fortis on this island. Boag (1981) has demonstrated parallel variation in this species on Is Santa Cruz with measurements of live birds.

The major source of geographical variation among populations of all species is between islands. Here we examine the possibility of systematic trends. We use a multiple linear regression analysis that employs a forward selection of variables to investigate statistical associations between population mean dimensions, estimated from male samples of 10 or more individuals, and 10 environmental variables that are correlated among themselves to varying degrees (see Abbott $e t$ al., 1977): island area, elevation, number of plant species, number of other Geospiza species, mean latitude and mean longitude of each island, and four measures of isolation; arithmetic average of distances to all other islands $(I I)$, distance to nearest island (I 2), distance to nearest large island (I 3) and distance to the central large island Is Santa Cruz (I 4) (see Fig. 1). Only Geospiza species are considered. G. conirostris has too few populations to be included. Forty analyses were performed; eight dimensions (hallux not included) for five species.

Statistical associations were found in only 17 analyses (Table 10). Variation in population means of $G$. scandens is not correlated with any of the chosen variables, and only one correlation is shown by $G$. fortis. Of the remainder, some of the correlations shown by G. magnirostris and G. difficilis would probably disappear if the extinct populations on Is Santa Maria and San Cristóbal were included. For example, Table 10 shows that size increases in $G$. magnirostris with 
Table 10. Results of multiple linear regression analyses of population means on ten environmental variables. Cumulative $R^{2}$ values are shown in parentheses. See text for explanation of the different isolation indices

\begin{tabular}{|c|c|c|c|c|c|}
\hline & G. magnirostris & G. fortis & G. fuliginosa & G. difficilis & G. scandens \\
\hline Wing & - Elevation $(0.5141)$ & & - Latitude (0.4788) & & \\
\hline Upper bill length & & & - Geospiza spp. (0.3319) & Longitude $(0.9189)$ & \\
\hline Lower bill length & - Area $(0.5440)$ & & -Geospiza spp. (0.3589) & Longitude $(0.9124)$ & \\
\hline Lipper bill depth & - Longitude (0.6909) & & - Latitude $(0.5359)$ & $\begin{array}{r}\text { - Isolation } 2(0.7644) \\
\text { Longitude }(0.9485)\end{array}$ & \\
\hline Lower bill depth & & & $\begin{array}{l}\text { - Geospiza spp. }(0.4561) \\
\text { - Isolation } 1(0.6097)\end{array}$ & & \\
\hline Upper bill width & & & - Latitude $(0.4446)$ & & \\
\hline Lower bill width & - Longitude (0.5167) & & $\begin{array}{l}\text { - Geospiza spp. (0.3659) } \\
\text { - Isolation } 4(0.5983)\end{array}$ & & \\
\hline Tarsus & Latitude $(0.8563)$ & - Latitude (0.3076) & Latitude $(0.6313)$ & & \\
\hline
\end{tabular}




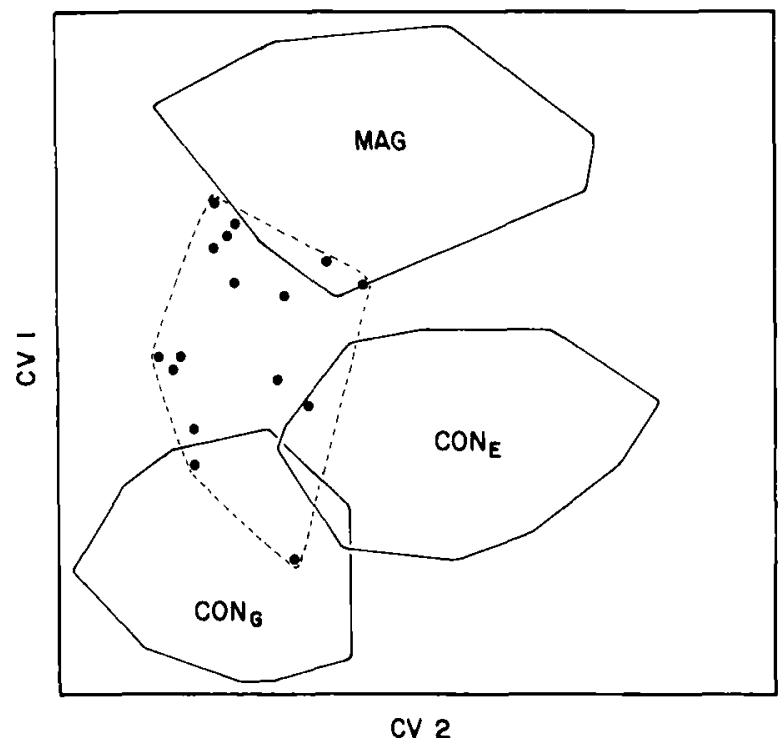

Figure 8. Canonical variates plot of eight populations of $G$. magnirostris (MAG), and, shown separately, populations of $G$. conirostris on Is Española $\left(\mathrm{CON}_{\mathrm{E}}\right)$ and Is Genovesa $\left(\mathrm{CON}_{\mathrm{G}}\right)$. Points refer to individuals (darwini) from Is Darwin. All specimens used in the analysis are males. CVI represents a size factor, increasing away from the origin, and CV2 represents a shape factor, with the bill becoming blunter (deeper, but relatively shorter), away from the origin. The analysis was performed without the darwini specimens: these were projected onto the axes calculated from the remaining individuals.

decreasing elevation (wing), decreasing area (bill length), towards the east (bill depth and width) and towards the north (tarsus). Inclusion of the especially large birds from the two southeastern islands would reinforce the longitudinal trend but weaken or eliminate the rest. Only $G$. fuliginosa shows strong and consistent trends: size is greatest in the south and on poorly isolated, species-rich islands.

The consistency in $G$. fuliginosa trends is partly the product of positive character correlations. Therefore as a second exercise we use PCl as the sole index of body size, and test for significant correlations with a reduced set of environmental variables: island area, elevation, number of plant species, mean latitude, mean longitude, and mean distance from other islands. Four tree finch species were added to the set of five ground finch species: Platyspiza crassirostris, Camarhynchus psittacula, C. parvulus and Certhidea olivacea.

Only four correlations $(r)$ were significant. Body size was correlated positively with degree of isolation for Certhidea olivacea $(P<0.01)$ and Camarhynchus parvulus $(P<0.05)$, positively with number of plant species for $G$. fortis $(P<0.05)$, and negatively with latitude for $G$. fuliginosa $(P<0.01)$. Six analyses were performed for each of nine species, therefore two of the 54 correlations are expected to be significant at the 5 per cent level by chance alone. We attach greatest importance to the results of $G$. fuliginosa and Certhidea olivacea because of the significance level $(P<0.01)$.

The overall results confirm Lack's (1947) conclusion that, in contrast to many mainland species of birds, Darwin's finches do not vary morphologically in a regular geographical manner. 
On small islands

Lack $(1945,1947)$ drew attention to the unusually small size of $G$. fortis on Is Daphne Major and the large size of $G$. fuliginosa on Los Hermanos (Crossmans). Our measurements of both museum and live specimens (Boag \& Grant, 1984a; Schluter et al., 1985) confirm this. The islands are very small ( $<40$ ha). Compared with the conspecific samples from the respective neighbouring islands of Is Santa Cruz and Is Isabela, Daphne $G$. fortis are significantly smaller $(P \ll 0.05)$ in all dimensions (males and females analysed separately), while Hermanos G. fuliginosa (males) are significantly larger in wing length, upper bill length and lower bill width. Comparisons of unpublished measurements of live birds on Daphne Major, B. Borrero on the north shore of Santa Cruz, Hermanos and Cerro Ballena on the east shore of Isabela have confirmed these differences (see Boag \& Grant, 1984a).

Two other populations on small islands are clearly different from relatives on adjacent large islands. On Is Tortuga, as on Hermanos, G. fuliginosa is significantly larger in beak length and width. On Is Gardner, G. conirostris is significantly smaller in beak length and width, and in tarsus length, than on nearby Is Española.

Samples from other small islands are very small $(\mathcal{N} \leqslant 8)$. There are significant differences between small islands and nearby large island means of one or two dimensions involving $G$. fuliginosa on Is Enderby, Is Cowley, Is Gardner by Floreana and Is Caldwell, and G. scandens on Is Champion and Is Gardner by Floreana. These differences may not be biologically meaningful, because some or all of the birds on the small islands may be immatures which had immigrated from the large islands. This is a probably correct explanation for the particularly small size of $G$. fortis on Is Cowley: all dimensions are significantly smaller than on nearby Is Isabela. The birds were collected on Is Cowley outside the breeding season in 1906. The next visit to Is Cowley was made in the breeding season of 1978, and only G. fuliginosa was observed (P. T. Boag, pers. comm.). Therefore $G$. fortis may have never been a breeding species on the island. Likewise $G$. scandens may not have bred on Is Gardner by Floreana, or else it may have become extinct, because in August 1979 one of us (P.R.G.) failed to find it (see also Grant \& Schluter, 1984).

Despite the uncertain status of these small island populations the measurements are sufficient to show that none is as distinctive as $G$. fortis on Is Daphne Major and G. fuliginosa on Los Hermanos, and there is no morphological trend on small islands.

\section{Geographical trends in population variation}

We used the same multiple linear regression procedure as before, but substituted coefficients of variation for population means, to investigate statistical associations between population variation and environmental variables. Fourteen of 40 analyses yielded significant results (Table 11). The trends are for population variation to increase with increasing isolation and with number of other Geospiza species on the island. This result is interesting because these two factors negatively covary. Variation also increase from north to south in two cases, but in the opposite direction in another; and variation increases 
Table 11. Results of multiple linear regression analyses of population coefficients of variation on ten environmental variables. Cumulative $R^{2}$ values are shown in parentheses. See text for explanation of the different measures of isolation

\begin{tabular}{|c|c|c|c|c|c|}
\hline & G. magnirostris & G. fortis & G. fuliginosa & G. difficilis & G. scandens \\
\hline Wing & Geospiza spp. (0.7058) & $\begin{array}{l}\text { Isolation } 2(0.4118) \\
\text { Geospiza spp. }(0.6869) \\
\text { - Plant spp. }(0.8094) \\
\text { - Latitude }(0.8948)\end{array}$ & & & \\
\hline Upper bill length & & Isolation $2(0.4245)$ & Geospiza spp. (0.2811) & Longitude $(0.8017)$ & \\
\hline Upper bill depth & & Isolation $2(0.3597)$ & Latitude $(0.2778)$ & & $\begin{array}{l}\text { - Latitude }(0.3758) \\
\text { Longitude }(0.7754) \\
\text { Isolation }(0.9113)\end{array}$ \\
\hline Lower bill depth & & Isolation $2(0.4921)$ & & & \\
\hline Upper bill width & & Isolation $4(0.4168)$ & Geospiza spp. (0.2665) & & \\
\hline Lower bill width & & $\begin{array}{l}\text { Isolation } 2(0.6402) \\
\text { Geosbiza spp }(0.8091)\end{array}$ & & & \\
\hline Tarsus & & Isolation $4(0.5959)$ & Longitude $(0.2765)$ & & \\
\hline
\end{tabular}


from east to west in three cases. Where correlations were strongest in G. fuliginosa in a geographical analysis of means, they are strongest in $G$. fortis in this analysis of variation. $G$. fortis is generally the most varying species (Table 5).

Stresemann (1936) hypothesized that poorly isolated populations of Darwin's finches exchange genes more frequently than well isolated populations and at a rate that retards, but does not prevent, differentiation. As a result, well isolated populations are more differentiated but less variable than less isolated ones. Lack (1945, 1947) and Hamilton \& Rubinoff (1967) have assembled evidence in support of differentiation being a function of isolation, but the relationship with variation has not been examined before. Stresemann's hypothesis is not supported by the positive correlations between coefficients of variation and degree of isolation in Table 11.

A more direct test of the hypothesized inverse relationship is performed by first constructing an index of overall variation for a population, for example by summing coefficients of variation for all traits (Van Valen, 1974), and then correlating this with some measure of differentiation of the population. A multivariate index of differentiation can be obtained from the Mahalanobis $D^{2}$ distance of each population from the group mean. We restrict attention to the bill dimensions, as did Grant (1979) in a comparable analysis of Fringilla coelebs (chaffinch) populations on eight islands in the Azores.

The expected significant inverse relationship was not observed for any of the five Geospiza species. Non-significant negative correlation coefficients were obtained for $G$. magnirostris $(r=-0.57 ; P>0.1), \quad G$. difficilis $(r=-0.56$; $P>0.1)$ and $G$. fortis $(r=-0.08 ; P>0.1)$. But the correlation for $G$. fuliginosa was positive and significant $(r=0.63 ; P<0.01)$. This analysis was performed a second time following deletion of two outliers, the smallest (Marchena) and largest (Hermanos) populations which are much more differentiated than the rest. The correlation for the remaining 13 populations was still significant $(r=0.57 ; P<0.05)$. Therefore the results of this more direct test do not support Stresemann's hypothesis, and are inconsistent with the pattern exhibited by Atlantic island chaffinches (Grant, 1979). They are not without parallels, however. Power (1983) found the least two differentiated populations of Carpodacus mexicanus (house finch) on Californian islands to have the lowest coefficients of variation.

Since overall bill variation was also found to be a positive function of island elevation in the Fringilla study (Grant, 1979), we repeated the multiple linear regression analyses with the variation index as the dependent variable. The only significant result was a positive association between variation in $G$. scandens populations and the number of other Geospiza species on the island $\left(R^{2}=0.6751\right)$; none of the correlations with island elevation approached significance. In a final set of analyses we used the differentiation index as the dependent variable, and again obtained only one significant result. The differentiation of $G$. magnirostris populations increased with distance from Is Santa Cruz $\left(R^{2}=0.8599\right)$; in simple correlation analyses it increased significantly with three of the four isolation indices. Although this is the only statistically significant association in support of the arguments of Stresemann, Lack and Hamilton and Rubinoff, there is a trend in all species; all correlation coefficients for differentiation and the four measures of isolation were positive in 
$G$. fortis, G. fuliginosa and $G$. difficilis, and in the case of $G$. scandens two were positive and two were negative.

\section{DISCUSSION}

Several of our results have substantiated Lack's (1945, 1947) conclusions concerning morphological variation among populations of the same species and between different species. These results have been obtained by using data and techniques not available to Lack: weights measured in the field, and multivariate analyses and statistical procedures facilitated by a computer. Thus we have been able to show that (1) populations of the same species differ largely in size, (2) species differ conspicuously from each other in shape, especially bill shape, as well as in size in most instances, (3) the most differentiated species, i.e. those showing the most variation among populations, are $G$. difficilis and Certhidea olivacea, and the least differentiated species is Platyspiza crassirosiris, (4) size variation among populations of the same species is generally not related systematically to latitude or longitude; $G$. scandens provides a good example of the typically mosaic pattern of variation in the archipelago, and (5) the populations of $G$. fortis on Is Daphne Major and $G$. fuliginosa on Is Los Hermanos are, among small island populations, the most distinctive.

The quantitative description of size and shape is not only more comprehensive, it has been extended in three areas. First, the allometric relations between dimensions among populations of the same species have been demonstrated by bivariate analysis. This has shown that wing and tarsus length covary in a very similar manner among all Geospiza species, whereas the relationship between bill length and bill width (or depth) differs markedly among these species. Second, it has been shown that tree finches are characterized by relatively long tarsi. Some of these species also have a relatively long hallux, as do those ground finches that spend much time either climbing on cacti or scratching on the ground. The close association between form and habit makes an adaptive explanation plausible. Parallel findings with Australian species of birds have been reported by Keast (1968).

Third, it has been shown that a tree finch species and a ground finch species overlap in principal component plots (two cases) whereas no two species within each group overlap. This result lies between two extreme alternatives; that the tree finch species and the ground finch species are entirely separable morphologically, and that each species in one group is the exact morphological counterpart of a species in the other group, only differing from it in plumage and habits. Thus there is some degree of morphological complementarity between the species of the two groups, but it is not exact.

Interpretation of these morphological patterns requires ecological study of food supply and feeding habits of the finches on each of the islands. The general paucity of strong geographical trends in our analyses can be explained by the absence from them of critical ecological data. For example it has been shown that inter-island variation in mean sizes of bill traits in Geospiza species is governed by inter-island variation in food supply, modified to some extent by the presence or absence of congeneric competitors (Abbott et al., 1977; Smith $e t$ al., 1978; Grant \& Grant, 1982; Schluter \& Grant, 1982; Boag \& Grant, 1984a; Grant, 1984; Grant \& Schluter, 1984; Schluter \& Grant, 1984a; Schluter et al., 1985). Therefore bill and body size variation show few simple geographical trends 
probably because the pertinent characteristics of the food supply do not vary geographically in a simple way (Abbott et al., 1977).

Population variation also is influenced by food supply (Bowman, 1961; Grant et al., 1976; Abbott et al., 1977; Grant \& Price, 1981). Theoretical considerations and field studies have identified another important influence, hybridization (Grant \& Price, 1981; Boag \& Grant, 1984a, b). The paucity of simple geographical trends in population variation, in contrast to the results of a study of island chaffinches (Grant, 1979), can be explained in part by the fact that our analysis did not directly account for this factor. The likelihood of hybridization entered the analysis only in a highly indirect form as the number of other Geospiza species on an island. This is unsatisfactory because the probability of hybridization depends on which particular species coexist, as well as on how many, and which particular non-resident species immigrate (Grant \& Price, 1981; Ratcliffe \& Grant, 1983a; Boag \& Grant, 1984a, b). Despite these and other shortcomings, coefficients of variation in G. magnirostris, G. fortis and $G$. fuliginosa increased with increasing numbers of coexisting congeners (Table 11) perhaps because this reflects a hybridization frequency directly proportional to the number of sympatric congeners. Coefficients of variation are unusually high in Darwin's finch populations (Table 5), and hybridization may be the most important responsible factor (Grant \& Price, 1981; Boag \& Grant, 1984a). Hybridization (with immigrant $G$. fortis) may be the cause of the only bimodal tendency in frequency distributions, manifested by the Los Hermanos population of $G$. fuliginosa (see also Lack, 1945, 1947).

Within each genus, species are identical in plumage (Geospiza, Camarhynchus) or nearly so (Cactospiza). They are distinguished by size, and in particular by the size and shape of the bill (Lack, 1945, 1947). Since individual specimens in museum collections are classified to species principally by their bill dimensions it may seem circular to claim that species differ from each other most in those features which we choose to be diagnostic. At the least it calls into question the reality of the species so recognized as collections of interbreeding individuals. Recent field studies have produced no evidence to disturb the classifications based on museum specimens. Males of species so classified sing different songs (Bowman, 1979, 1983; Ratcliffe \& Grant, 1985), and discriminate between these songs and those of other species (Ratcliffe \& Grant, 1985). Discrimination between conspecific and heterospecific models differing only in bill size has also been demonstrated experimentally (Lack, 1945, 1947; Ratcliffe \& Grant, 1983a, b). Finally interbreeding between species classified by morphological (bill) criteria is very infrequent, whereas breeding within such species is extensive (Grant \& Grant, 1980; Grant \& Price, 1981; Boag \& Grant, 1984b). Therefore the morphological classification of museum specimens of Darwin's finch species is sound.

\section{ACKNOWLEDGEMENTS}

We thank the following museum curators for the loan of specimens and, in some cases, the provision of study facilities: D. Amadon and L. L. Short (American, New York), J. C. Barlow (Royal Ontario), C. W. Benson (Cambridge), J. Dorst (Paris), C. Edelstam (Stockholm), G. F. Mees (Leiden), R. T. Orr and L. Baptista (California Academy of Sciences), K. C. Parkes 
(Carnegie), R. Paynter (Harvard), P. Morgan (Liverpool), J. C. Reichholf (Munich), D. W. Snow (British, Tring), R. W. Storer (Michigan) and M. A. Traylor (Field, Chicago). P. Rosset and M. Stromberg kindly gave help with the computing, which was done at McGill University, Montreal, Canada, at the University of $W$ Australia and at the University of Michigan, U.S.A. Funds were provided by grants from the National Research Council of Canada and National Science Foundation of the U.S.A. to P.R.G., and from the Department of Soil Science at the University of W Australia to I. A. B. R. Grant and T. D. Price made helpful comments on the manuscript.

\section{REFERENCES}

ABBOTT, I., ABBOTT, L. K. \& GRANT, P. R., 1977. Comparative ecology of Galapagos Ground Finche's (Geospiza Gould): evaluation of the importance of floristic diversity and interspecific competition. Ecological Monographs, 47: 151-184.

BOAG, P. T., 1981. Morphological variation in the Darwin's finches (Geospizinae) of Daphne Major Island, Galapagos. Unpublished $\mathrm{Ph} . \mathrm{D}$. thesis, McGill University, Montreal.

BOAG, P. T., 1983. The heritability of external morphology in Darwin's 'ground finches (Geospiza) on Isla Daphne Major, Galápagos. Evolution, 37: 877-894.

BOAG, P. T. \& GRANT, P. R., 1978. Heritability of external morphology in Darwin's finches. . Vature, 274: 793-794.

BOAG, P. T. \& GRAN'T, P. R., 1981. Intense natural selection in a population of Darwin's finches (Geospizinae) in the Galápagos. Science, 214: 82-85.

BOAG, P. T. \& GRANT, P. R., 1984a. The classical case of character release: Darwin's finches (Geospiza on Isla Daphne Major, Galápagos. Biological Journal of the Linnean Society, 22: 243-287.

BOAG, P. T. \& GRANT, P. R., 1984b. Darwin's finches (Geospiza) on Isla Daphne Major, Galápagow: brecding and feeding ecology in a climatically variable environment. Ecological Monographs, 54: 463-489.

BOWMAN, R. I., 1961. Morphological differentiation and adaptation in the Galápagos finches. University of California Publications in Zoology, 58: 1-302.

BOWMAN, R. I., 1979. Adaptive morphology of song dialects in Darwin's finches. Journal fü Omithologie, 120: 353-389.

BOWMAN, R. I., 1983. The evolution of song in Darwin's finches. In R. I. Bowman, M. Berson \& A. E. Leviton (Eds), Patterns of Evolution in Galápagos Organisms: 237-537. American Association for the Advancement of Science, Pacific Division, San Francisco.

CURIO, E. \& KRAMER, P., 1965. Geospiza conirostris auf Abingdon und Wenman entdeckt. Journal fiur Ornithologie, 106: 355-357.

DOWNHOWER, J. F., 1976. Darwin's finches and the evolution of sexual dimorphism in body size. Falure, 263: 558-563.

FLESSA, K. W. \& BRAY, R. G., 1977. On the measurement of size-independent morphological variability: an example using successive populations of a Devonian spiriferid brachiopod. Paleobiology, 3: $350-359$.

GOULD, S. J. \& JOHNSTON, R. F., 1972. Geographic variation. Annual Reviews of Ecology and Systematics, 3: 457-498.

GOULD, J., 1837. Description of new species of finches collected by Darwin in the Galápagos. Proceedings of the Zoological Society of London, 5: 4-7.

GRANT, B. R. \& GRANT, P. R., 1979. Darwin's finches: population variation and sympatric speciation. Proceedings of the National Academy of Sciences, U.S.A., 76: $2359-2363$.

GRANT, B. R. \& GRAN'T, P. R., 1981. Exploitation of Opuntia cactus by birds on the Galápagos. Oecologia. 49: 179-187.

GRANT, B. R. \& GRANT, P. R., 1982. Niche shifts and competition in Darwin's finches: Geospiza conirosiris and congeners. Evolution, 36: 637-657.

GRANT, B. R. \& GRANT, P. R., 1983. Fission and fusion in a population of Darwin's finches: an example of the value of studying individuals in ecology. Oikos, 4l: 530-547.

GRANT, P. R., 1979. Evolution of the chaffinch, Fringilla coelebs, on the Atlantic Islands. Biological Journal of the Linnean Society, 11: 301-332.

GRANT, P. R., 1981a. Speciation and the adaptive radiation of Darwin's finches. American Scientist, 69: 653-663.

GRANT, P. R,, 1981b. Patterns of growth in Darwin's finches. Proceedings of the Roval Society of London B, 212. 403-432.

GRANT, P. R., 1983. Inheritance of size and shape in a population of Darwin's finches, Geospiza conirostris. Proceedings of the Royal Society of London B, 220: 219-236.

GRANT, P. R., 1984. Recent research on the evolution of land birds on the Galápagos. Biologicat fournal of the Linnean Sociely, 21: 113-136. 
GRANT, P. R. \& GRANT, B. R., 1980. The breeding and fecding characteristics of Darwin's finche's on Isla Genovesa, Galápagos. Ecological Monographs, 50: $381-410$.

GRAN'T, P. R., GRANT, B. R., SMITH, J. N. M., ABBOT”I, I. J. \& ABBO'I'I', L. K., 1976. Darwin's finches: population variation and natural sclection. Procedings of the National Academy of Sciences, L.S.A., 73: $257-261$

GRANT, P. R. \& PRICE, T. D., 1981. Population variation in continuously varying traits as an ecological genctics problem. American Zoologist, 21: 795-811.

GRANT, P. R. \& SCHLUTER, D., 1984. Interspecific competition inferred from patterns of guild structure. In D. R. Strong, D. Simberloff, L. G. Abele \& A. B. Thistle (Eds), Ecological communities: conceptual issues and the evidence: 201-233. Princeton: Princeton University Press.

HAMILTON, T. H. \& RUBINOFF, I., 1967. On predicting insular variation in endemism and sympatry for the Darwin finches in the Galápagos archipelago. American Naturalist, 101: 161-171.

HARRIS, M. P., 1974. A field guide to the birds of Galapagos. London, Collins.

HARVEY, P. H. \& MACE, G. M., 1982. Comparisons between taxa and adaptive trends: problems of methodology. In P. P. G. Bateson (Ed.), Current Problems in Sociobiology: 343-361. Cambridge: Cambridge University Press.

HUMPHRIES, J. M., BOOKSTEIN, F. L., CHERNOFF, B., SMITH, G. R., ELDER, R. L. \& POSS, S. G., 1981. Multivariate discrimination by shape in relation to size. Systematic Zoology, 30: 291-308.

JOHNSTON, R. F. \& SELANDER, R. K., 1973, Evolution in the House Sparrow. 11I. Variation in size and sexual dimorphism in Europe and North and South America. American Naturalist, 107: 373-390.

KEAST, A., 1968. Competitive interactions and the evolution of ecological niches as illustrated by the Australian Honeyeater genus Melithreptus (Meliphagidac). Evolution, 22: 762-784.

KUNKEL, J. G., CHERRY, L. M., CASE, S. M. \& WILSON, A. C., 1980. M-statistics and morphometric divergence. Science, 208: 1060-1061.

LACK, D., 1945. The Galápagos finches (Geospizinae): a study in variation. Occasional Papers of the California Academy of Sciences, 21: 1-159.

LACK, D. 1947. Darwin's finches. Cambridge: Cambridge University Press.

MOSIMANN, J. E. \& JAMES, F. C., 1979. New statistical methods for allometry with application to Florida Red-winged Blackbirds. Evolution, 33: 444-459.

POWER, D. M., 1983. Variability in island populations of the House Finch. Auk, 100: 180-187.

PRICE, T. D., 1984. The evolution of sexual size dimorphism in Darwin's finches. American Naturalist, 123: $500-518$.

PRICE, T. D. \& GRANT, P. R., 1984. Life history traits and natural selection for small body size in a population of Darwin's finches. Evolution, 38: 483-494.

PRICE, T. D., GRANT, P. R. \& BOAG, P. T., 1984. Genetic changes in the morphological differentiation of Darwin's ground finches. In K. Wöhrmann \& V. Loeschcke (Eds), Population Biology and Evolution: 49-66. New York: Springer.

RA'TCLIFFE, L. M., 1981. Species recognition in Darwin's ground finches Geospiza, Gould). Unpublished Ph.D. thesis, McGill University, Montreal.

RA'TCiLIFFE, L. M. \& GRANT, P. R., 1983a. Species recognition in Darwin's finches (Geospiza, Gould). II. Geographic variation in mate preference. Animal Behaviour, 31: 1154-1165.

RAT'CLIFFE, L. M. \& GRANT, P. R., 1983b. Species recognition in Darwin's finches (Geospiza, Gould). I. Discrimination by morphological cues. Animal Behaviour, 31: 1139-1153.

RATCLIFFE, L. M. \& GRANT, P. R., 1985. Species recognition in Darwin's finches (Geospiza, Gould). III. Male responses to song types, heterospecific song and dialects. Animal Behaviour, 33: 290-307.

ROHLF, F. J., GILMAR'TIN, A. J. \& HART, G., 1983. The Kluge-Kerfoot phenomenon-a statistical artifact. Evolution, 37: 180-202.

RO'IHSCHILD, W. \& HARTERT, E., 1899. A review of the ornithology of the Galapagos Islands. Novitates Zoologicae, 6: 85-205.

ROTHSCHILD, W. \& HARTERT, E., 1902. Further notes on the fauna of the Galápagos Islands. Novitates Zoologicae, 9: 381-418.

SCHLUTER, D., 1982. Distributions of Galápagos ground finches along an altitudinal gradient: the importance of food supply. Ecology, 63: 1504-1517.

SCHLU'IER, D. \& GRANT, P. R., 1982. The distribution of Geospiza difficilis in relation to G. fuliginosa in the Galápagos islands: a test of three hypotheses. Evolution, 36: 1213-1226.

SCHLUTER, D. \& GRANT, P. R., 1984a. Determinants of morphological patterns in communities of Darwin's finches. American Naturalist, 123: 175-196.

SCiHLUTER, D. \& GRANT, P. R., 1984b. Ecological correlates of morphological evolution in a Darwin's linch, Geospiza difficilis. Evolution, 38: 856-869.

SCHLUTER, D., PRICE, T. D. \& GRANT, P. R. 1985. Ecological character displacement in Darwin's finches. Science, 227: 1056-1059.

SMITH, J. N. M., GRANT, P. R., GRANT, B. R., ABBOTT, I. J. \& ABBOTT, L. K., 1978. Seasonal variation in feeding habits of Darwin's ground finches. Ecology, 59: 1137-1150.

SNEDECOR, G. W. \& COCHRAN, W. G., 1967. Statistical Methods, 6th Edn. Ames: Iowa State University Press. 
SOKAL, R. R. \& ROHLF, F. J., 1981. Biometry, 2nd Edn. San Francisco: W. H. Freeman \& Sons.

STEADMAN, D. W., 1982. The origin of Darwin's finches. Transactions of the San Diego Society of Natural History, 19: 279-296.

STRESEMANN, E., 1936. Zur Frage der Artbildung in der Gattung Geospiza. Orgaan der Club Van Nederlandische Vogelkundigen, 9: 12-21.

SULLOWAY, F. J., 1982a. The Beagle collections of Darwin's finches (Geospizinae). Bulletin of the British Museum (Natural History), Zoology series, 43: 49-94.

SULlOWAY, F. J., 1982b. Darwin and his Finches: the evolution of a legend. Journal of the History of Biology, 15: $1-53$.

SWARTH, H. S., 1931. The avifauna of the Galápagos Islands. Occasional Papers of the California Academy of Sciences, 18: 1-299.

SWAR'TH, H. S., 1934. The bird fauna of the Galápagos Islands in relation to species formation. Biological Reviews, 9: 213-234.

VAN VALEN, L., 1974. Multivariate structural statistics in natural history. Journal of Theoretical Biology, 45: 235-247.

VAN VALEN, L., 1978. The statistics of variation. Evolutionary Theory, 4: 33-43.

YANG, S. H. \& PATTON, J. L., 1981. Genic variability and differentiation in Galápagos finches. Auk, 98: 230-242.

\section{APPENDIX}

\section{Taxonomic problems}

There is no general agreement on whether there are three genera of tree finches (Swarth, 1931; Bowman, 1961; Yang \& Patton, 1981), two (Harris, 1974) or one (Lack, 1947). We have recognized three in Table 1 and the text, for reasons discussed by Bowman (1961) and by Lack (1947). Judgements on generic limits are based on a consideration of variation in all traits including plumage, and plumage assessment is beyond the scope of this paper. Note that Steadman (1982) advocates placing all 14 species in a single genus.

One other matter of naming is problematical. The first name given to a form of the sharp beaked ground finch, by Gould (1837) was Geospiza nebulosa. Owing to subsequent confusion concerning the identity and source island of the specimens the name Geospiza difficilis Sharpe came to replace G. nebulosa. Through thorough historical researches Sulloway (1982a, b) has been able to identify two of the missing specimens in the British Museum (a third is in the Royal Stockholm Museum), and there is little doubt that the source island is Is Floreana (Santa María). Our measurements of these three specimens show that this form is clearly related to other populations of $G$. difficilis (Fig. 6). Sulloway (1982a, b) has made a cogent argument for reinstating the name nebulosa in place of difficilis. Since $G$. difficilis has been the name used for the species in the modern treatments by Lack $(1945,1947)$ and Bowman (1961), as well as in all our own publications, we continue using it here while recognizing the force of Sulloway's arguments. The issue is currently being considered by the International Commission on Zoological Nomenclature.

Remaining problems concern the status of two species.

(1) Geospiza conirostris. Lack's $(1945,1947)$ taxonomic judgements have been widely accepted, except for the number of genera he recognized (Bowman, 1961). At the species level, the most difficult problem for him to resolve was the status of $G$. conirostris. This is summarized in the first footnote to his table III (Lack, 1947: 18): "Geospiza conirostris has obvious affinities with G. scandens and replaces it geographically, but it is so distinctive that it is given a separate specific name. It should perhaps be reckoned as part of the G. scandens superspecies, but this is not certain". 
$G$. conirostris as currently recognized is known to have three breeding populations; on Is Española and its satellite Is Gardner (G. c. conirostris) and on Is Genovesa ( $G$. c. propinqua). It has been reported on Is Pinta and Is Wolf (Curio \& Kramer, 1965), but extensive field work on these islands in the last 10 years has failed to detect its presence (Schluter, 1982; Schluter \& Grant, 1984a). It has also been reported on Is Darwin; for this situation, see below.

The distinctive feature of $G$. conirostris is lateral flattening of the bill, in which the species is more similar to the tree finches than are any of the other ground finch species. In particular, the base of the lower mandible of $G$. conirostris is flatter and less convex in profile than it is in all other Geospiza species. However, some individuals of $G$. scandens from Is Marchena resemble some individuals of $G$. conirostris from the adjacent island of Genovesa in this feature. We have not quantified it, but made our comparisons by placing museum specimens side by side. Clearly these two populations are similar, and it is conceivable that gene flow occurs between them even today (Grant \& Grant, 1982).

Despite these similarities the overall size and shape of the bill in these two populations differ substantially. For example in Fig. 6 note the large distance between the polyhedra of these two species, particularly along the shape axis PC2. G. conirostris on Is Genovesa and $G$. scandens on Is Marchena are much more similar to conspecifics elsewhere than they are to each other. The populations of $G$. conirostris on Is Española and Is Gardner are slightly closer, in Fig. 6, to G. magnirostris and G. forlis. On the only island (Genovesa) where $G$. conirostris is sympatric with one of those congeners (G. magnirostris), interbreeding is extremely infrequent (Grant \& Grant, 1982). For these reasons we continue to consider $G$. conirostris as a distinctive species.

(2) Geospiza conirostris darwini. An extension of the above problem is the status of the 34 specimens of large finches on Is Darwin (Culpepper), all collected within 10 years of each other at the turn of the century. Despite their exceptional variability, Lack (1947: 26) concluded: ". . they all belong to darwini. The beak of darwini shows clear basic affinities with that of other forms of $G$. conirostris, but is heavier with superficial similarities to that of G. magnirostris". The resemblance to G. magnirostris, he explained, "is probably due to parallel evolution, as it is the type of beak which would be expected in a form of $G$. conirostris which had become specialized primarily for ground feeding" (p. 68). In assigning all specimens to $G$. conirostris darwini, Lack (1947) followed Rothschild \& Hartert $(1899,1902)$.

Bowman (1961: 269), in contrast, upheld the view of Swarth (1931) that the Is Darwin birds belong to two species, $G$. magnirostris and $G$. conirostris propinqua (from Is Genovesa). Bowman (1961) corrected an error in Lack's calculations and showed that the coefficient of variation in bill depth of males $(\mathcal{N}=16)$ was 13.13, an extremely large value.

To help resolve the issue we performed a multiple discriminant function analysis of male samples of all G. magnirostris populations $(\mathcal{N}=8)$ and G. conirostris populations $(\mathcal{N}=3)$, excluding the sample of males from Is Darwin. Figure 8 shows the results on the first two canonical variates axes. The 16 males from Is Darwin are projected on to the axes.

Several important points can be seen. First, there is relatively little differentiation among the $G$. magnirostris populations, hence a single composite 
polyhedron is shown for the species. In contrast, the samples of $G$. conirostris from Is Genovesa and Is Española are almost entirely separated from each other; the Is Gardner sample is not shown because it is almost identical to the Is Española sample. Second, most specimens from Is Darwin do not fall into the polyhedrons of either species. Most fall in the space between $G$. magnirostris and $G$. conirostris from Is Genovesa. Third, there appears to be a bimodality in CV1 scores among the Is Darwin specimens, i.e. on the first (size) axis, eight specimens are closely allied to the $G$. magnirostris distribution and eight are closer to the $G$. conirostris (Genovesa) distribution. This reflects the two size classes perceived by Swarth (1931). The analysis provides a quantification of the taxonomic problem without indicating a solution.

We also examined the curvature of the sides of the bills (tomia) and the lateral base of the lower mandibles, as in the analysis of affinities between $G$. conirostris and $G$. scandens. In this unquantified feature, the bills of all of the Is Darwin specimens had the convex curvature of most members of the genus Geospiza, and not the flatter aspect of the bills of $G$. conirostris. On this basis and from the results of the discriminant function analysis we conclude that $G$. conirostris, as a species, is not represented by any of the specimens in museum collections.

The species on Is Darwin is either an unusual form of $G$. magnirosiris or it deserves to be recognized as distinctive, $G$. darwini following Rothschild \& Hartert (1899). The extreme variation in bill dimensions, tending towards bimodality, suggests genetic heterogeneity due to mixing. Either the species has interbred with $G$. difficilis, the only sympatric congener on the island, or else with an immigrant species: if the immigrant species was G. conirostris, the distinctive bill feature of that species was lost in subsequent generations. Whatever the origin of the heterogeneity it is unique among Darwin's finches.

Lack (1947) considered the possibility of a hybrid origin of the species but thought it was improbable because he had no evidence of interbreeding between $G$. magnirostris and $G$. conirostris on Is Genovesa: evidence has been obtained since then (Grant \& Grant, 1982). Nevertheless recent evidence obtained elsewhere from the archipelago makes an interbreeding hypothesis plausible. On Is Daphne Major interbreeding occurs occasionally between $G$. fortis and immigrant $G$. fuliginosa and resident $G$. scandens (Grant \& Price, 1981; Boag \& Grant, 1984a, b). Interbreeding has the potential of elevating phenotypic and genetic variances (Grant \& Price, 1981), given the high heritabilities of the major metric traits (Boag \& Grant, 1978; Boag, 1983; Grant, 1983).

The finches on Is Darwin would clearly repay further study, yet the physical difficulties are formidable as the slopes of the island are too steep to be climbed. The only visit to the top of the island was made by helicopter in 1964, and in one afternoon no large finches were seen (R. I. Bowman, pers. comm.). However, on a visit in 1980 by sea to the rocky slope where the specimens had been collected earlier, one of us (D.S.) saw two individuals. One was captured and had a deep bill like that of a typical $G$. magnirostris. The other was not captured but was seen to have a longer and more pointed bill.

We conclude that the population is $G$. magnirostris, but strongly influenced by genes ultimately of heterospecific origin. We have listed it as $G$. magnirostris, in the Appendix tables, and have included it in only the bivariate analyses in Figs $3 \& 4$. 
(3) Geospiza magnirostris. Five males and three females were collected on Islas Floreana and San Cristóbal by members of the Beagle expedition in 1835. In the present study we measured all but the two specimens collected by $\mathrm{S}$. Covington on Is Floreana and now in the British Museum of Natural History. The two unmeasured specimens resemble the others in wing length, bill length and bill depth (Sulloway, 1982a). The combined samples from the two islands (Appendix Tables Al-A5) have larger mean wing and tarsus lengths than other populations (Fig. 3). From the relationships between wing and tarsus length on the one hand and weight on the other (Fig. 2) we estimate the weights of these birds to have been about $45 \mathrm{~g}$ on average, perhaps extending maximally beyond $50 \mathrm{~g}$. They were thus the largest and heaviest of all Darwin's finches.

They are more distinctive in beak size (Fig. 4). They clearly differ from conspecific populations along PC2, a beak size and shape axis, but not on PC1, a body size axis (Fig. 7). The degree to which they differ from other G. magnirostris populations in bill dimensions is striking (Fig. 4), and is much more pronounced than is the distinctiveness of the problematical population on Is Darwin.

The question arises as to whether the populations on Islas Floreana and San Cristóbal really were conspecific with other G. magnirostris populations or whether they constituted a separate species. If the latter is correct they would retain the name magnirostris, and all other populations treated as magnirostris should be called $G$. strenua, the name given by Gould (1837). Swarth (1931), impressed by the confusion over their island(s) of origin, considered the specimens to be particularly large individuals from Is San Salvador, and Lack (1945) followed Swarth's taxonomic judgement. But the confusion over their origin has been removed by the historical researches of Sulloway (1982a); and all individuals are exceptionally large.

There is an interesting possibility that on San Cristóbal, at least, the large and typical forms of $G$. magnirostris were present together. One, and possibly three, specimens of the large form (magnirostris) were collected on this island (Sulloway, 1982a). Also collected on this island was at least one specimen of strenua (sensu Gould), by Fitzroy, and possibly two or three were collected by Darwin. Sulloway (1982a) has argued that one of Darwin's specimens was an unusually large $G$. fortis; that the other two were too small to be part of the species represented by the large form (magnirostris), and were therefore probably collected on another island (San Salvador); and that Fitzroy's specimen was probably a hybrid between $G$. fortis and the large form of $G$. magnirostris. If the island of origin has been correctly identified as San Cristóbal, however, the totals are one to three specimens of magnirostris and three or four specimens of strenua. They may have been sympatric species.

Since the populations on Is Floreana and Is San Cristóbal are now extinct we will never have a firm answer to the question of their taxonomic status. Fossils may shed light on the problem by showing, for example, that along one or more dimensions there is a peak between the frequency distributions of measurements that are obviously assignable to $G$. fortis and $G$. magnirostris. In view of all these uncertainties we have taken the conservative view here that the unusually large finches on these two islands are conspecific with $G$. magnirostris elsewhere in the archipelago. 
Table Al. Sample size $(\mathcal{N})$, mean $(\overline{\mathbf{x}})$ and standard deviation (s.D.) for wing length (mm) of Geospiza species. The samples of G. magnirostris from Islas Floreana and San Cristóbal have been combined under the heading Floreana in this and subsequent tables: see the Appendix text for a discussion of the taxonomic status of these populations and the population of G. magnirostris on Is Darwin

\begin{tabular}{|c|c|c|c|c|c|c|}
\hline & \multicolumn{3}{|c|}{$0^{*}$} & \multicolumn{3}{|c|}{ qक } \\
\hline & $\mathcal{N}$ & $\overline{\mathbf{x}}$ & S.D. & $\mathcal{N}$ & $\overline{\mathbf{x}}$ & S.D. \\
\hline \multicolumn{7}{|l|}{ G. magnirostris } \\
\hline Santa Cruz & 27 & 82.3 & 2.74 & 16 & 78.6 & 2.00 \\
\hline San Salvador & 57 & 83.4 & 2.69 & 37 & 80.6 & 2.56 \\
\hline Rábida & 40 & 83.3 & 2.72 & 17 & 80.4 & 2.62 \\
\hline Isabela & 7 & 80.9 & 3.24 & 8 & 79.9 & 3.48 \\
\hline Genovesa & 38 & 86.5 & 2.56 & 23 & 82.8 & 2.21 \\
\hline Marchena & 53 & 81.9 & 3.06 & 19 & 78.3 & 2.66 \\
\hline Pinta & 62 & 82.6 & 2.57 & 36 & 80.7 & 2.16 \\
\hline Wolf & 8 & 87.2 & 2.31 & 4 & 84.2 & 1.71 \\
\hline Darwin & 16 & 84.4 & 3.28 & 8 & 80.1 & 3.60 \\
\hline Floreana & 4 & 89.0 & 1.41 & 2 & 87.0 & - \\
\hline \multicolumn{7}{|l|}{ G. fortis } \\
\hline Española & 4 & 70.7 & 0.96 & 7 & 70.0 & 1.91 \\
\hline Floreana & 278 & 72.8 & 2.73 & 229 & 69.7 & 2.33 \\
\hline Gardner/Floreana & 4 & 73.7 & 2.87 & 5 & 70.8 & 3.70 \\
\hline Champion & 4 & 73.0 & 2.94 & - & - & - \\
\hline San Cristóbal & 134 & 73.1 & 3.24 & 87 & 70.9 & 2.68 \\
\hline Santa Fe & 9 & 74.9 & 2.57 & 4 & 68.2 & 4.03 \\
\hline Santa Cruz & 159 & 72.8 & 3.23 & 110 & 70.5 & 3.16 \\
\hline Baltra & 25 & 72.6 & 2.63 & 30 & 69.3 & 2.68 \\
\hline Daphne & $3 !$ & 68.6 & 1.78 & 11 & 65.9 & 1.81 \\
\hline San Salvador & 86 & 71.9 & 2.22 & 57 & 69.5 & 2.65 \\
\hline Rábida & 11 & 72.3 & 1.74 & 11 & 69.0 & 1.41 \\
\hline Pinzón & 39 & 68.9 & 3.05 & 30 & 68.6 & 2.53 \\
\hline Cowley & 5 & 70.4 & 2.07 & - & - & - \\
\hline Isabela & 198 & 73.2 & 3.39 & 127 & 70.8 & 3.12 \\
\hline Fernandina & 14 & 71.6 & 1.86 & 3 & 70.0 & 2.00 \\
\hline Marchena & 44 & 67.4 & 1.47 & 25 & 64.6 & 1.35 \\
\hline Pinta & 59 & 66.0 & 2.24 & 28 & 63.3 & 1.84 \\
\hline \multicolumn{7}{|l|}{ G. fuliginosa } \\
\hline Española & 37 & 64.7 & 1.82 & 20 & 62.3 & 2.13 \\
\hline Gardner/Española & 12 & 64.2 & 2.52 & 6 & 61.8 & 1.17 \\
\hline Floreana & 97 & 64.0 & 1.99 & 101 & 62.1 & 1.51 \\
\hline Gardner/Floreana & 8 & 65.4 & 2.50 & 4 & 62.2 & 1.50 \\
\hline Caldwell & 3 & 65.0 & 2.65 & - & - & - \\
\hline Enderby & 8 & 64.7 & 1.39 & 7 & 61.3 & 2.50 \\
\hline San Cristóbal & 150 & 64.2 & 1.82 & 126 & 62.1 & 1.73 \\
\hline Santa Fe & 50 & 63.7 & 1.71 & 12 & 61.4 & 1.88 \\
\hline Santa Cruz & 134 & 64.0 & 1.62 & 70 & 61.5 & 1.77 \\
\hline Baltra & 47 & 64.3 & 1.63 & 28 & 61.6 & 1.39 \\
\hline Bartolomé & 5 & 63.4 & 2.19 & - & - & \\
\hline San Salvador & 39 & 63.8 & 2.12 & 24 & 62.2 & 2.06 \\
\hline Rábida & 14 & 64.0 & 1.57 & 12 & 61.8 & 1.85 \\
\hline Pinzón & 98 & 64.1 & 1.74 & 32 & 61.8 & 1.62 \\
\hline Cowley & 4 & 63.5 & 2.65 & 4 & 62.0 & 1.41 \\
\hline Hermanos & 12 & 66.5 & 1.79 & 5 & 63.2 & 2.59 \\
\hline Tortuga & 11 & 64.7 & 1.49 & 7 & 62.6 & 0.53 \\
\hline Isabela & 202 & 64.5 & 1.78 & 149 & 61.7 & 1.68 \\
\hline Fernandina & 27 & 64.8 & 1.87 & 17 & 62.7 & 1.86 \\
\hline Marchena & 39 & 59.2 & 2.09 & 30 & 57.1 & 1.92 \\
\hline Pinta & 63 & 59.8 & 1.78 & 43 & 58.7 & 1.87 \\
\hline
\end{tabular}


Table Al. Continued

\begin{tabular}{|c|c|c|c|c|c|c|}
\hline & \multicolumn{3}{|c|}{$\partial 0^{0}$} & \multicolumn{3}{|c|}{99} \\
\hline & $\mathcal{N}$ & $\overline{\mathbf{x}}$ & S.D. & $\mathcal{N}$ & $\overline{\mathrm{x}}$ & S.D. \\
\hline \multicolumn{7}{|l|}{ G. difficilis } \\
\hline Floreana & 1 & 72 & - & 2 & 71.5 & - \\
\hline Santa Cruz & 31 & 70.3 & 1.30 & 10 & 68.7 & 1.10 \\
\hline San Salvador & 52 & 73.0 & 1.80 & 25 & 70.8 & 1.44 \\
\hline Genovesa & 83 & 63.4 & 2.02 & 44 & 61.3 & 1.68 \\
\hline Pinta & 19 & 63.4 & 1.39 & 15 & 62.5 & 1.30 \\
\hline Wolf & 100 & 72.9 & 1.84 & 49 & 70.1 & 1.61 \\
\hline Darwin & 39 & 74.4 & 2.03 & 9 & 71.3 & 1.58 \\
\hline \multicolumn{7}{|l|}{ G. scandens } \\
\hline Floreana & 141 & 71.6 & 1.97 & 92 & 69.3 & 1.76 \\
\hline Gardner/Floreana & 4 & 71.0 & 1.15 & - & - & - \\
\hline Champion & 4 & 72.5 & 1.29 & 6 & 68.5 & 1.76 \\
\hline San Cristóbal & 6 & 69.5 & 2.59 & 10 & 67.6 & 2.17 \\
\hline Santa Fe & 66 & 72.4 & 1.76 & 28 & 70.0 & 1.89 \\
\hline Santa Cruz & 127 & 72.8 & 2.09 & 76 & 70.4 & 2.08 \\
\hline Baltra & 50 & 72.8 & 2.05 & 29 & 70.0 & 1.52 \\
\hline San Salvador & 29 & 70.7 & 1.64 & 17 & 67.6 & 1.66 \\
\hline Rábida & 23 & 71.8 & 2.33 & 13 & 68.8 & 1.40 \\
\hline Pinzón & 8 & 72.0 & 1.07 & 12 & 70.6 & 2.23 \\
\hline Isabela & 23 & 72.8 & 1.76 & 9 & 69.9 & 2.52 \\
\hline Marchena & 10 & 73.5 & 2.27 & 13 & 70.5 & 1.85 \\
\hline Pinta & 16 & 72.5 & 1.75 & 13 & 69.1 & 2.30 \\
\hline \multicolumn{7}{|l|}{ (j. conirostris } \\
\hline Española & 120 & 80.3 & 2.58 & 77 & 76.9 & 2.00 \\
\hline Gardner/Española & 76 & 79.5 & 2.61 & 50 & 76.4 & 2.18 \\
\hline Genovesa & 65 & 77.7 & 2.17 & 34 & 74.4 & 2.15 \\
\hline
\end{tabular}

Table A2. Sample size $(\mathcal{N})$, mean $(\overline{\mathbf{x}})$ and standard deviation (s.D.) for tarsus length $(\mathrm{mm})$ of each Geospiza species

\begin{tabular}{|c|c|c|c|c|c|c|}
\hline & \multicolumn{3}{|c|}{$\hat{\delta} \hat{\jmath}$} & \multicolumn{3}{|c|}{$q q$} \\
\hline & $\mathcal{N}$ & $\overline{\mathbf{x}}$ & S.D. & $\mathcal{N}$ & $\overline{\mathbf{x}}$ & S.D. \\
\hline \multicolumn{7}{|l|}{ G. magnirostris } \\
\hline Santa Cruz & 27 & 21.03 & 0.96 & 16 & 20.23 & 0.80 \\
\hline San Salvador & 57 & 20.98 & 1.01 & 37 & 20.80 & 0.98 \\
\hline Rábida & 40 & 20.71 & 0.63 & 17 & 20.51 & 0.57 \\
\hline Isabela & 7 & 20.53 & 1.23 & 8 & 20.49 & 1.15 \\
\hline Genovesa & 38 & 21.45 & 0.88 & 22 & 21.12 & 1.15 \\
\hline Marchena & 54 & 21.04 & 0.80 & 20 & 20.79 & 1.07 \\
\hline Pinta & 62 & 21.36 & 0.76 & 36 & 20.39 & 0.94 \\
\hline Wolf & 8 & 22.22 & 1.35 & 4 & 20.60 & 1.56 \\
\hline Darwin & 16 & 21.92 & 0.70 & 8 & 21.36 & 0.84 \\
\hline Floreana & 4 & 22.18 & 0.63 & 2 & 21.25 & - \\
\hline \multicolumn{7}{|l|}{ G. fortis } \\
\hline Española & 4 & 18.75 & 0.83 & 7 & 18.26 & 0.89 \\
\hline Floreana & 278 & 18.81 & 0.84 & 228 & 18.23 & 0.69 \\
\hline Gardner/Floreana & 4 & 18.72 & 1.47 & 5 & 18.36 & 0.74 \\
\hline Champion & 4 & 18.77 & 1.21 & 一 & - & - \\
\hline San Cristóbal & 134 & 19.12 & 0.84 & 87 & 18.69 & 0.76 \\
\hline Santa Fe & 9 & 19.06 & 0.64 & 4 & 18.22 & 0.66 \\
\hline Santa Cruz & 160 & 18.82 & 0.87 & 110 & 18.16 & 0.76 \\
\hline Baltra & 25 & 18.76 & 0.76 & 30 & 18.04 & 0.79 \\
\hline Daphne & 31 & 17.75 & 0.81 & 11 & 17.01 & 0.73 \\
\hline
\end{tabular}


Table A2. Continued

\begin{tabular}{|c|c|c|c|c|c|c|}
\hline & \multicolumn{3}{|c|}{$3 \sigma^{*}$} & \multicolumn{3}{|c|}{ 우 } \\
\hline & $\mathcal{N}$ & $\overline{\mathbf{x}}$ & S.D. & $\mathcal{N}$ & $\overline{\mathbf{x}}$ & s.D. \\
\hline San Salvador & 86 & 18.54 & 0.68 & 57 & 18.02 & 0.91 \\
\hline Rábida & 11 & 19.01 & 0.52 & 11 & 18.11 & 0.70 \\
\hline Pinzón & 39 & 17.94 & 0.94 & 30 & 17.79 & 0.95 \\
\hline Cowley & 5 & 18.62 & 0.29 & - & - & - \\
\hline Isabela & 197 & 19.03 & 1.04 & 127 & 18.59 & 0.82 \\
\hline Fernandina & 14 & 18.30 & 0.70 & 3 & 17.40 & 1.04 \\
\hline Marchena & 44 & 17.23 & 0.85 & 25 & 16.86 & 0.74 \\
\hline Pinta & 58 & 17.20 & 0.73 & 28 & 16.45 & 0.55 \\
\hline \multicolumn{7}{|l|}{ G. fuliginosa } \\
\hline Española & 37 & 17.12 & 0.71 & 20 & 16.49 & 0.78 \\
\hline Gardner/Española & 12 & 17.24 & 0.78 & 6 & 16.40 & 0.54 \\
\hline Florcana & 97 & 17.19 & 0.57 & 101 & 16.69 & 0.63 \\
\hline Gardner/Floreana & 8 & 17.21 & 0.55 & 4 & 16.65 & 0.40 \\
\hline Caldwell & 3 & 16.30 & 0.61 & - & - & - \\
\hline Enderby & 8 & 16.44 & 0.47 & 7 & 15.84 & 0.24 \\
\hline San Cristóbal & 148 & 17.13 & 0.66 & 125 & 16.66 & 0.77 \\
\hline Santa $\mathrm{Fe}$ & 50 & 16.77 & 0.68 & 12 & 16.43 & 0.82 \\
\hline Santa Cruz & 132 & 16.97 & 0.57 & 70 & 16.50 & 0.53 \\
\hline Baltra & 46 & 16.88 & 0.56 & 27 & 16.47 & 0.64 \\
\hline Bartolomé & 5 & 17.02 & 0.38 & - & - & - \\
\hline San Salvador & 39 & 17.08 & 0.62 & 24 & 16.73 & 0.66 \\
\hline Rábida & 14 & 17.03 & 0.75 & 12 & 16.30 & 0.74 \\
\hline Pinzón & 98 & 16.99 & 0.65 & 32 & 16.47 & 0.47 \\
\hline Cowley & 4 & 17.32 & 0.61 & 4 & 17.22 & 0.74 \\
\hline Hermanos & 12 & 17.22 & 0.74 & 5 & 16.78 & 0.85 \\
\hline Tortuga & 11 & 16.77 & 0.53 & 7 & 16.60 & 0.54 \\
\hline Isabela & 201 & 17.06 & 0.56 & 149 & 16.65 & 0.69 \\
\hline Fernandina & 27 & 16.85 & 0.82 & 17 & 16.64 & 0.61 \\
\hline Marchena & 38 & 15.53 & 0.49 & 30 & 15.14 & 0.72 \\
\hline Pinta & 62 & 15.71 & 0.75 & 41 & 15.39 & 0.66 \\
\hline \multicolumn{7}{|l|}{ G. difficilis } \\
\hline Floreana & 1 & 18.9 & - & 2 & 20.7 & - \\
\hline Santa Cruz & 31 & 18.61 & 0.94 & 10 & 18.90 & 0.80 \\
\hline San Salvador & 52 & 19.66 & 0.98 & 25 & 19.09 & 1.21 \\
\hline Genovesa & 83 & 16.37 & 0.74 & 44 & 15.91 & 0.64 \\
\hline Pinta & 19 & 17.17 & 1.11 & 15 & 17.12 & 0.99 \\
\hline Wolf & 100 & 18.77 & 0.58 & 49 & 18.03 & 0.67 \\
\hline Darwin & 39 & 19.26 & 0.72 & 10 & 18.71 & 0.81 \\
\hline \multicolumn{7}{|l|}{ G. scandens } \\
\hline Floreana & 141 & 18.80 & 0.76 & 92 & 18.29 & 0.64 \\
\hline Gardner/Floreana & 4 & 18.60 & 0.53 & - & - & - \\
\hline Champion & 4 & 17.50 & 1.19 & 6 & 18.23 & 0.61 \\
\hline San Cristóbal & 6 & 17.98 & 1.07 & 10 & 17.78 & 0.87 \\
\hline Santa Fe & 66 & 19.13 & 0.78 & 28 & 18.42 & 0.62 \\
\hline Santa Cruz & 126 & 19.11 & 0.67 & 76 & 18.74 & 0.70 \\
\hline Baltra & 50 & 19.17 & 0.49 & 29 & 18.48 & 0.60 \\
\hline San Salvador & 29 & 18.33 & 1.03 & 17 & 18.01 & 0.90 \\
\hline Rábida & 23 & 18.70 & 0.71 & 13 & 17.85 & 0.71 \\
\hline Pinzón & 8 & 18.99 & 0.51 & 12 & 18.49 & 1.00 \\
\hline Isabela & 23 & 19.06 & 0.66 & 9 & 18.67 & 0.71 \\
\hline Marchena & 9 & 19.34 & 0.81 & 13 & 18.57 & 0.97 \\
\hline Pinta & 16 & 19.28 & 0.39 & 13 & 18.50 & 0.53 \\
\hline \multicolumn{7}{|l|}{ G. conirostris } \\
\hline Española & 120 & 20.06 & 0.75 & 76 & 19.43 & 0.64 \\
\hline Gardner/Española & 76 & 19.61 & 0.81 & 50 & 19.20 & 0.94 \\
\hline Genovesa & 65 & 20.67 & 0.80 & 34 & 20.02 & 0.78 \\
\hline
\end{tabular}


Table A3. Sample size $(\mathcal{N})$, mean $(\overline{\mathbf{x}})$ and standard deviation (s.D.) for upper mandible length $(\mathrm{mm})$ of each Geospiza species

\begin{tabular}{|c|c|c|c|c|c|c|}
\hline & \multicolumn{3}{|c|}{00} & \multicolumn{3}{|c|}{ १९ } \\
\hline & $\mathcal{N}$ & $\overline{\mathbf{x}}$ & S.D. & $\mathcal{N}$ & $\overline{\mathbf{x}}$ & S.D. \\
\hline \multicolumn{7}{|l|}{ G. magnirostris } \\
\hline Santa Cruz & 27 & 14.94 & 0.82 & 16 & 14.63 & 0.70 \\
\hline San Salvador & 57 & 15.55 & 1.21 & 37 & 15.01 & 1.14 \\
\hline Rábida & 40 & 15.11 & 0.75 & 17 & 14.73 & 0.80 \\
\hline Isabela & 7 & 14.67 & 1.25 & 8 & 14.18 & 1.24 \\
\hline Genovesa & 38 & 16.07 & 1.00 & 23 & 15.81 & 0.78 \\
\hline Marchena & 54 & 14.96 & 0.72 & 20 & 14.73 & 0.98 \\
\hline Pinta & 62 & 15.78 & 0.75 & 36 & 15.41 & 0.66 \\
\hline Wolf & 8 & 15.36 & 0.59 & 4 & 15.92 & 0.29 \\
\hline Darwin & 16 & 14.69 & 1.07 & 8 & 14.79 & 1.19 \\
\hline Floreana & 4 & 17.98 & 0.71 & 2 & 17.35 & - \\
\hline \multicolumn{7}{|l|}{ G. fortis } \\
\hline Española & 4 & 10.95 & 0.40 & 7 & 11.27 & 0.78 \\
\hline Floreana & 278 & 11.26 & 0.90 & 227 & 10.91 & 0.80 \\
\hline Gardner/Floreana & 4 & 11.55 & 1.13 & 5 & 11.10 & 1.23 \\
\hline Champion & 4 & 11.40 & 1.00 & - & - & - \\
\hline San Cristóbal & 134 & 11.96 & 0.75 & 87 & 11.75 & 0.78 \\
\hline Santa $\mathrm{Fe}$ & 9 & 12.30 & 1.22 & 4 & 10.92 & 0.50 \\
\hline Santa Cruz & 159 & 11.66 & 0.87 & 110 & 11.46 & 0.75 \\
\hline Baltra & 25 & 11.22 & 0.69 & 30 & 11.14 & 0.65 \\
\hline Daphne & 31 & 10.26 & 0.58 & 11 & 10.08 & 0.77 \\
\hline San Salvador & 85 & 11.16 & 0.63 & 56 & 11.01 & 0.83 \\
\hline Rábida & 11 & 11.27 & 0.47 & 11 & 11.04 & 0.61 \\
\hline Pinzón & 39 & 10.68 & 0.78 & 30 & 10.85 & 0.86 \\
\hline Cowley & 5 & 10.70 & 0.41 & - & -- & - \\
\hline Isabela & 198 & 11.55 & 1.03 & 126 & 11.29 & 0.95 \\
\hline Fernandina & 14 & 11.24 & 0.38 & 3 & 11.13 & 0.65 \\
\hline Marchena & 44 & 11.36 & 0.53 & 25 & 11.16 & 0.47 \\
\hline Pinta & 59 & 10.93 & $0.6 \mathrm{l}$ & 28 & 10.76 & 0.57 \\
\hline \multicolumn{7}{|l|}{ G. fuliginosa } \\
\hline Española & 37 & 8.39 & 0.33 & 20 & 8.25 & 0.43 \\
\hline Gardner/Española & 12 & 8.30 & 0.49 & 6 & 8.03 & 0.51 \\
\hline Floreana & 97 & 8.33 & 0.40 & 101 & 8.13 & 0.51 \\
\hline Gardner/Floreana & 8 & 8.66 & 0.49 & 4 & 8.42 & 0.32 \\
\hline Caldwell & 3 & 8.50 & 0.20 & - & - & - \\
\hline Enderby & 8 & 7.89 & 0.48 & 7 & 7.93 & 0.39 \\
\hline San Cristóbal & 149 & 8.53 & 0.69 & 125 & 8.37 & 0.69 \\
\hline Santa $\mathrm{Fe}$ & 50 & 8.49 & 0.42 & 11 & 8.06 & 0.22 \\
\hline Santa Cruz & 134 & 8.18 & 0.46 & 70 & 8.08 & 0.49 \\
\hline Baltra & 47 & 8.29 & 0.43 & 27 & 8.18 & 0.35 \\
\hline Bartolomé & 5 & 8.10 & 0.19 & - & - & - \\
\hline San Salvador & 38 & 8.14 & 0.38 & 24 & 8.30 & 0.51 \\
\hline Rábida & 14 & 8.19 & 0.46 & 12 & 8.14 & 0.34 \\
\hline Pinzón & 98 & 8.32 & 0.39 & 32 & 8.27 & 0.32 \\
\hline Cowley & 3 & 7.97 & 0.70 & 4 & 7.07 & 0.39 \\
\hline Hermanos & 12 & 9.00 & 0.96 & 5 & 8.84 & 0.81 \\
\hline Tortuga & 11 & 8.59 & 0.40 & 7 & 8.40 & 0.28 \\
\hline Isabela & 201 & 8.04 & 0.39 & 149 & 7.90 & 0.37 \\
\hline Fernandina & 27 & 7.76 & 0.58 & 17 & 7.73 & 0.49 \\
\hline Marchena & 38 & 7.78 & 0.34 & 30 & 7.68 & 0.32 \\
\hline Pinta & 62 & 8.02 & 0.42 & 43 & 7.81 & 0.44 \\
\hline \multicolumn{7}{|l|}{ G. difficilis } \\
\hline Floreana & 1 & 10.5 & - & 2 & 10.95 & $\cdots$ \\
\hline Santa Cruz & $3 !$ & 9.25 & 0.33 & 10 & 9.14 & 0.55 \\
\hline San Salvador & 52 & 9.89 & 0.44 & 25 & 9.72 & 0.36 \\
\hline
\end{tabular}


Table A3. Continued

\begin{tabular}{|c|c|c|c|c|c|c|}
\hline & \multicolumn{3}{|c|}{$80^{\circ}$} & \multicolumn{3}{|c|}{ qq } \\
\hline & $\mathcal{N}$ & $\overline{\mathbf{x}}$ & s.D. & $\mathcal{N}$ & $\overline{\mathbf{x}}$ & S.D. \\
\hline Genovesa & 83 & 9.06 & 0.50 & 43 & 8.96 & 0.48 \\
\hline Pinta & 19 & 9.34 & 0.57 & 15 & 9.17 & 0.36 \\
\hline Wolf & 100 & 10.45 & 0.47 & 49 & 10.36 & 0.44 \\
\hline Darwin & 38 & 11.13 & 0.42 & 10 & 10.89 & 0.53 \\
\hline \multicolumn{7}{|l|}{ G. scandens } \\
\hline Floreana & 140 & 13.39 & 0.77 & $9 !$ & 13.10 & 0.78 \\
\hline Gardner/Floreana & 4 & 12.85 & 0.81 & - & - & - \\
\hline Champion & 4 & 13.02 & 0.94 & 6 & 12.65 & 0.72 \\
\hline San Cristóbal & 6 & 13.02 & 0.93 & 10 & 12.35 & 1.11 \\
\hline Santa Fe & 66 & 14.08 & 0.78 & 28 & 13.77 & 0.80 \\
\hline Santa Cruz & 125 & 14.53 & 1.02 & 74 & 14.35 & 0.93 \\
\hline Baltra & 49 & 14.47 & 0.85 & 29 & 14.42 & 0.66 \\
\hline San Salvador & 29 & 12.68 & 0.66 & 17 & 12.06 & 0.87 \\
\hline Rábida & 23 & 13.15 & 0.62 & 13 & 13.18 & 1.12 \\
\hline Pinzón & 8 & 14.36 & 0.55 & 12 & 13.79 & 0.95 \\
\hline Isabela & 23 & 14.06 & 0.83 & 9 & 13.64 & 1.03 \\
\hline Marchena & 10 & 14.90 & 0.57 & 13 & 14.47 & 0.64 \\
\hline Pinta & 16 & 14.27 & 0.52 & 13 & 13.78 & 0.91 \\
\hline \multicolumn{7}{|l|}{ G. conirostris } \\
\hline Española & 119 & 15.03 & 1.08 & 77 & 14.55 & 0.98 \\
\hline Gardner/Española & 76 & 14.36 & 0.97 & 49 & 13.77 & 0.98 \\
\hline Genovesa & 64 & 14.06 & 0.85 & 33 & 13.69 & 0.59 \\
\hline
\end{tabular}

Table A4. Sample size $(\mathcal{N})$, mean $(\overline{\mathbf{x}})$ and standard deviation (s.D.) for upper mandible depth in millimetres of each Geospiza species

\begin{tabular}{|c|c|c|c|c|c|c|}
\hline & \multicolumn{3}{|c|}{38} & \multicolumn{3}{|c|}{ 우 } \\
\hline & $\mathcal{N}$ & $\overline{\mathbf{x}}$ & S.D. & $\mathcal{N}$ & $\overline{\mathrm{x}}$ & S.D. \\
\hline \multicolumn{7}{|l|}{ G. magnirostris } \\
\hline Santa Cruz & 27 & 7.68 & 0.97 & 16 & 7.37 & 0.86 \\
\hline San Salvador & 57 & 8.30 & 0.77 & 37 & 7.72 & 0.81 \\
\hline Rátbida & 40 & 7.65 & 0.49 & 17 & 7.25 & 0.54 \\
\hline Isabela & 7 & 6.99 & 0.84 & 8 & 7.17 & 0.74 \\
\hline Genovesa & 38 & 8.53 & 0.70 & 23 & 8.52 & 0.70 \\
\hline Marchena & 54 & 7.85 & 0.66 & 20 & 7.48 & 0.84 \\
\hline Pinta & 62 & 8.31 & 0.63 & 36 & 7.86 & 0.57 \\
\hline Wolf & 8 & 7.59 & 0.89 & 4 & 7.90 & 0.50 \\
\hline Darwin & 16 & 6.61 & 1.04 & 8 & 6.05 & 0.65 \\
\hline Floreana & 4 & 9.45 & 0.37 & 2 & 9.20 & \\
\hline \multicolumn{7}{|l|}{ G. fortis } \\
\hline Española & 4 & 5.22 & 0.26 & 7 & 5.27 & 0.40 \\
\hline Floreana & 278 & 5.29 & 0.57 & 229 & 5.13 & 0.45 \\
\hline Gardner/Floreana & 4 & 5.30 & 1.04 & 5 & 4.92 & 0.08 \\
\hline Champion & 4 & 5.25 & 0.26 & - & & - \\
\hline San Cristóbal & 134 & 5.60 & 0.60 & 87 & 5.49 & 0.59 \\
\hline Santa Fe & 9 & 5.51 & 0.72 & 4 & 4.50 & 0.56 \\
\hline Santa Cruz & 158 & 5.26 & 0.65 & 110 & 5.08 & 0.58 \\
\hline Baltra & 25 & 5.27 & 0.46 & 30 & 4.96 & 0.52 \\
\hline
\end{tabular}


Table A4. Continued

\begin{tabular}{|c|c|c|c|c|c|c|}
\hline & & 30 & & & $q q$ & \\
\hline & $N$ & $\overline{\mathbf{x}}$ & S.D. & $N$ & $\overline{\mathbf{x}}$ & S.D. \\
\hline Daphne & 31 & 4.38 & 0.45 & 11 & 4.31 & 0.27 \\
\hline San Salvador & 86 & 5.26 & 0.48 & 57 & 5.12 & 0.53 \\
\hline Rábida & 11 & 5.17 & 0.47 & 11 & 5.14 & 0.57 \\
\hline Pinzón & 39 & 4.82 & 0.58 & 30 & 5.03 & 0.60 \\
\hline Cowley & 5 & 4.62 & 0.26 & - & $-:$ & - \\
\hline Isabela & 198 & 5.37 & 0.74 & 127 & 5.27 & 0.68 \\
\hline Fernandina & 14 & 5.30 & 0.23 & 3 & 5.23 & 0.38 \\
\hline Marchena & 44 & 4.98 & 0.46 & 25 & 4.88 & 0.42 \\
\hline Pinta & 59 & 4.80 & 0.45 & 28 & 4.49 & 0.38 \\
\hline (i. fuliginosa & & & & & & \\
\hline Española & 37 & 3.59 & 0.24 & 20 & 3.55 & 0.22 \\
\hline Gardner/Española & 12 & 3.57 & 0.29 & 6 & 3.68 & 0.12 \\
\hline Floreana & 96 & 3.49 & 0.28 & 101 & 3.48 & 0.22 \\
\hline Gardner/Floreana & 8 & 3.55 & 0.45 & 4 & 3.27 & 0.46 \\
\hline Caidwell & 3 & 3.27 & 0.20 & - & - & - \\
\hline Enderby & 8 & 3.36 & 0.47 & 7 & 3.37 & 0.27 \\
\hline San Cristóbal & 150 & 3.54 & 0.34 & 126 & 3.44 & 0.33 \\
\hline Santa $\mathrm{Fe}$ & 50 & 3.47 & 0.27 & 12 & 3.38 & 0.31 \\
\hline Santa Cruz & 135 & 3.38 & 0.32 & 70 & 3.39 & 0.27 \\
\hline Baltra & 47 & 3.57 & 0.29 & 28 & 3.39 & 0.28 \\
\hline Bartolomé & 5 & 3.22 & 0.37 & - & - & \\
\hline San Salvador & 39 & 3.39 & 0.30 & 24 & 3.36 & 0.47 \\
\hline Rábida & 14 & 3.38 & 0.25 & 12 & 3.17 & 0.37 \\
\hline Pinzón & 98 & 3.46 & 0.26 & 32 & 3.49 & 0.27 \\
\hline Cowley & 4 & 3.25 & 0.47 & 4 & 3.30 & 0.62 \\
\hline Hermanos & 12 & 3.54 & 0.51 & 5 & 3.42 & 0.48 \\
\hline 'lortuga & 11 & 3.64 & 0.29 & 7 & 3.57 & 0.31 \\
\hline Isabela & 202 & 3.50 & 0.32 & 149 & 3.43 & 0.30 \\
\hline Fernandina & 27 & 3.42 & 0.41 & 17 & 3.33 & 0.31 \\
\hline Marchena & 39 & 3.12 & 0.26 & 30 & 2.97 & 0.29 \\
\hline Pinta & 63 & 3.28 & 0.32 & 43 & 3.19 & 0.29 \\
\hline (i. difficilis & & & & & & \\
\hline Floreana & 1 & 4.4 & - & 2 & 4.00 & 一 \\
\hline Santa Cruz & 31 & 4.22 & 0.42 & 10 & 4.25 & 0.29 \\
\hline San Salvador & 52 & 4.50 & 0.41 & 25 & 4.38 & 0.37 \\
\hline Genovesa & 83 & 3.25 & 0.31 & 44 & 3.18 & 0.33 \\
\hline Pinta & 19 & 3.75 & 0.42 & 15 & 3.78 & 0.25 \\
\hline Wolf & 100 & 3.78 & 0.29 & 49 & 3.64 & 0.28 \\
\hline Darwin & 39 & 4.08 & 0.40 & 10 & 3.99 & 0.34 \\
\hline Gi. scandens & & & & & & \\
\hline Floreana & 141 & 4.33 & 0.31 & 92 & 4.21 & 0.30 \\
\hline Garduer/Floreana & 4 & 4.37 & 0.27 & - & - & - \\
\hline Champion & 4 & 4.02 & 0.51 & 6 & 3.77 & 0.50 \\
\hline San Cristóbal & 6 & 4.25 & $0.4 \mathrm{I}$ & 10 & 4.02 & 0.64 \\
\hline Santa $\mathbf{F e}$ & 66 & 4.63 & 0.37 & 28 & 4.44 & 0.45 \\
\hline Santa Cruz & 127 & 4.41 & 0.41 & 75 & 4.23 & 0.38 \\
\hline Baltura & 50 & 4.47 & 0.35 & 29 & 4.27 & 0.40 \\
\hline San Salvador & 29 & 3.77 & 0.40 & 17 & 3.81 & 0.35 \\
\hline Rábida & 23 & 4.08 & 0.50 & 13 & 4.21 & 0.50 \\
\hline Pinzón & 8 & 4.35 & 0.53 & 12 & 4.37 & 0.25 \\
\hline Isabela & 23 & 4.49 & 0.42 & 9 & 4.21 & 0.31 \\
\hline Marchena & 10 & 4.92 & 0.37 & 13 & 4.70 & 0.37 \\
\hline Pinta & 16 & 4.52 & 0.33 & 13 & 4.36 & 0.35 \\
\hline G. conirostris & & & & & & \\
\hline Española & 120 & 6.24 & 0.62 & 77 & 5.97 & 0.57 \\
\hline Gardner/Española & 76 & 6.17 & 0.47 & 50 & 5.82 & 0.53 \\
\hline Genovesa & 65 & 5.70 & 0.50 & 34 & 5.44 & 0.57 \\
\hline
\end{tabular}


Table A5. Sample size $(\mathcal{N})$, mean $(\overline{\mathbf{x}})$ and standard deviation (s.D.) for lower mandible width ( $\mathrm{mm}$ ) of each Geospiza species

\begin{tabular}{|c|c|c|c|c|c|c|}
\hline & \multicolumn{3}{|c|}{$0^{\circ}$} & \multicolumn{3}{|c|}{90} \\
\hline & $\mathcal{N}$ & $\overline{\mathbf{x}}$ & s.D. & $\mathcal{N}$ & $\overline{\mathbf{x}}$ & S.D. \\
\hline \multicolumn{7}{|l|}{ G. magnirostris } \\
\hline Santa Cruz & 27 & 14.56 & 1.10 & 16 & 13.88 & 0.99 \\
\hline San Salvador & 57 & 15.07 & 1.20 & 37 & 14.64 & 1.09 \\
\hline Rábida & 40 & 13.73 & 0.67 & 17 & 13.29 & 0.94 \\
\hline Isabela & 7 & 13.69 & 1.12 & 8 & 13.39 & 1.73 \\
\hline Genovesa & 38 & 15.87 & 0.69 & 23 & 15.56 & 0.47 \\
\hline Marchena & 54 & 14.32 & 0.85 & 20 & 13.72 & 1.01 \\
\hline Pinta & 62 & 15.24 & 0.80 & 36 & 14.44 & 0.63 \\
\hline Wolf & 8 & 14.86 & 0.52 & 4 & 14.35 & 0.29 \\
\hline Darwin & 16 & 12.56 & 1.55 & 8 & 11.91 & 1.29 \\
\hline Floreana & 4 & 17.43 & 1.09 & 2 & 16.85 & $\cdots$ \\
\hline \multicolumn{7}{|l|}{ G. fortis } \\
\hline Española & 4 & 8.87 & 0.29 & 7 & 9.54 & 0.56 \\
\hline Floreana & 276 & 9.56 & 1.05 & 229 & 9.05 & 0.72 \\
\hline Gardner/Floreana & 4 & 9.92 & 1.24 & 5 & 9.26 & 0.54 \\
\hline Champion & 4 & 9.47 & 0.75 & - & - & \\
\hline San Cristóbal & 134 & 10.21 & 0.93 & 87 & 9.80 & 0.91 \\
\hline Santa $\mathrm{Fe}$ & 9 & 10.19 & 0.92 & 4 & 8.87 & 0.56 \\
\hline Santa Cruz & 160 & 9.96 & 0.98 & 110 & 9.49 & 0.93 \\
\hline Baltra & 25 & 9.62 & 0.76 & 29 & 9.17 & 0.73 \\
\hline Daphne & 31 & 8.17 & 0.53 & 11 & 7.98 & 0.53 \\
\hline San Salvador & 86 & 9.56 & 0.66 & 57 & 9.38 & 0.86 \\
\hline Rábida & 11 & 9.84 & 0.45 & 11 & 9.24 & 0.49 \\
\hline Pinzón & 39 & 8.73 & 0.93 & 30 & 8.84 & 1.11 \\
\hline Cowley & 5 & 8.94 & 0.30 & - & - & 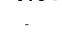 \\
\hline Isabela & 198 & 9.92 & 1.06 & 127 & 10.11 & 0.90 \\
\hline Fernandina & 14 & 9.36 & 0.34 & 3 & 9.13 & 0.25 \\
\hline Marchena & 44 & 9.17 & 0.46 & 25 & 9.14 & 0.40 \\
\hline Pinta & 59 & 9.04 & 0.64 & 28 & 8.58 & 0.42 \\
\hline \multicolumn{7}{|l|}{ G. fuliginosa } \\
\hline Española & 36 & 6.58 & 0.35 & 20 & 6.22 & 0.29 \\
\hline Gardner/Española & 11 & 6.58 & 0.25 & 6 & 6.28 & 0.31 \\
\hline Floreana & 97 & 6.54 & 0.31 & 100 & 6.27 & 0.29 \\
\hline Gardner/Floreana & 8 & 6.80 & 0.32 & 4 & 6.17 & 0.25 \\
\hline Caldwell & 3 & 6.60 & 0.17 & - & - & - \\
\hline Enderby & 8 & 6.57 & 0.49 & 7 & 6.27 & 0.34 \\
\hline San Cristóbal & 149 & 6.46 & 0.42 & 126 & 6.19 & 0.36 \\
\hline Santa $\mathrm{Fe}$ & 49 & 6.55 & 0.36 & 12 & 6.28 & 0.25 \\
\hline Santa Cruz & 135 & 6.48 & 0.29 & 70 & 6.28 & 0.29 \\
\hline Baltra & 46 & 6.57 & 0.30 & 28 & 6.39 & 0.26 \\
\hline Bartolomé & 5 & 6.60 & 0.23 & 一 & - & - \\
\hline San Salvador & 38 & 6.47 & 0.34 & 24 & 6.34 & 0.48 \\
\hline Rábida & 14 & 6.51 & 0.41 & 12 & 6.31 & 0.19 \\
\hline Pinźon & 98 & 6.57 & 0.30 & 31 & 6.41 & 0.26 \\
\hline Cowley & 4 & 6.20 & 0.53 & 4 & 6.05 & 0.17 \\
\hline Hermanos & 12 & 7.18 & 0.59 & 5 & 7.00 & 0.38 \\
\hline Tortuga & 11 & 6.85 & 0.35 & 7 & 6.59 & 0.21 \\
\hline Isabela & 201 & 6.53 & 0.32 & 148 & 6.38 & 0.27 \\
\hline Fernandina & 27 & 6.46 & 0.29 & 16 & 6.16 & 0.31 \\
\hline Marchena & 38 & 5.77 & 0.29 & 30 & 5.61 & 0.38 \\
\hline Pinta & 63 & 6.28 & 0.32 & 43 & 6.06 & 0.30 \\
\hline \multicolumn{7}{|l|}{ G. difficilis } \\
\hline Floreana & 1 & 8.0 & - & 2 & 8.85 & - \\
\hline Santa Cruz & 31 & 7.18 & 0.30 & 10 & 7.07 & 0.25 \\
\hline San Salvador & 50 & 7.68 & 0.43 & 24 & 7.39 & 0.26 \\
\hline
\end{tabular}


Table A5. Continued

\begin{tabular}{|c|c|c|c|c|c|c|}
\hline & \multicolumn{3}{|c|}{ 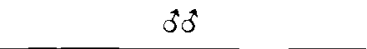 } & \multicolumn{3}{|c|}{90} \\
\hline & $\mathcal{N}$ & $\overline{\mathbf{x}}$ & S.D. & $\mathcal{N}$ & $\overline{\mathbf{x}}$ & S.D. \\
\hline Genovesa & 81 & 6.21 & 0.34 & 44 & 6.00 & 0.37 \\
\hline Pinta & 19 & 6.83 & 0.65 & 15 & 6.53 & 0.32 \\
\hline Wolf & 100 & 6.87 & 0.36 & 48 & 6.66 & 0.31 \\
\hline Darwin & 39 & 7.42 & 0.32 & 10 & 7.15 & 0.21 \\
\hline \multicolumn{7}{|l|}{ G. scandens } \\
\hline Floreana & 141 & 7.77 & 0.33 & 92 & 7.39 & 0.37 \\
\hline Gardner/Floreana & 4 & 7.90 & 0.11 & - & - & - \\
\hline Champion & 4 & 7.77 & 0.39 & 6 & 7.57 & 0.39 \\
\hline San Cristóbal & 6 & 7.72 & 0.32 & 10 & 7.42 & 0.56 \\
\hline Santa Fe & 66 & 8.08 & 0.44 & 28 & 7.68 & 0.32 \\
\hline Santa Cruz & 126 & 7.90 & 0.48 & 76 & 7.62 & 0.40 \\
\hline Baltra & 50 & 7.84 & 0.42 & 29 & 7.59 & 0.33 \\
\hline San Salvador & 29 & 7.25 & 0.45 & 17 & 6.75 & 0.40 \\
\hline Rábida & 22 & 7.56 & 0.45 & 13 & 7.41 & 0.52 \\
\hline Pinzón & 8 & 8.14 & 0.33 & 12 & 7.43 & 0.47 \\
\hline Isabela & 23 & 7.90 & 0.50 & 9 & 7.22 & 0.43 \\
\hline Marchena & 10 & 8.69 & 0.56 & 13 & 8.40 & 0.54 \\
\hline Pinta & 16 & 8.07 & 0.48 & 13 & 7.45 & 0.56 \\
\hline \multicolumn{7}{|l|}{ G. conirostris } \\
\hline Española & 119 & 11.71 & 0.92 & 77 & 11.00 & 0.76 \\
\hline Gardner/Española & 76 & 11.25 & 0.77 & 50 & 10.74 & 0.82 \\
\hline Genovesa & 65 & 9.79 & 0.74 & 34 & 9.45 & 0.75 \\
\hline
\end{tabular}

